\title{
Alkene and Carbon Monoxide Insertion Reactions of Nitrogen-Coordinated Monoorganopalladium(II) Complexes: The Stepwise Construction of Alternating Copolymers of CO and Alkenes on a Palladium(II) Center
}

\author{
Bertus A. Markies, ${ }^{\dagger}$ Dennis Kruis, ${ }^{\dagger}$ Marco H. P. Rietveld, ${ }^{\dagger}$ Kai A. N. Verkerk, ${ }^{\dagger}$ \\ Jaap Boersma, ${ }^{*, \dagger}$ Huub Kooijman, ${ }^{\ddagger}$ Miles T. Lakin, ${ }^{\ddagger}$ Anthony L. Spek, ${ }^{\ddagger, \beta}$ and \\ Gerard van Koten ${ }^{\dagger}$
}

Contribution from the Debye Institute, Department of Metal-Mediated Synthesis, and the Bijvoet Center for Biomolecular Research, Laboratory of Crystal and Structural Chemistry, Utrecht University, Padualaan 8, $3584 \mathrm{CH}$ Utrecht, The Netherlands

Received July $12,1994^{\otimes}$

\begin{abstract}
The stepwise synthesis of a palladium(II) bound alternating oligomer of $\mathrm{CO}$ and strained alkenes is described together with the factors that allow full control of each successive step. The sequence starts with acetylpalladium(II) complexes $\mathrm{PdX}(\mathrm{COMe})(\mathrm{N}-\mathrm{N})(\mathbf{2}, 4),\left(\mathrm{X}=\mathrm{Cl}(\mathbf{a}), \mathrm{Br}(\mathbf{b})\right.$, or $\mathrm{I}(\mathbf{c}) ; \mathrm{N}-\mathrm{N}=N, N, N^{\prime}, N^{\prime}$-tetramethylethylenediamine (tmeda) or 2,2'-bipyridyl (bpy)). The bpy-coordinated acetyl complexes $(\mathbf{4 a - c})$ show an unexpected isomerization reaction of the groups around the metal center for which thermodynamic parameters have been determined. A mechanism for the isomerization is proposed. The ionic complexes $[\mathrm{Pd}(\mathrm{COMe})(\mathrm{MeCN})(\mathrm{N}-\mathrm{N})] \mathrm{OTf}(\mathbf{5}, \mathbf{6}$; OTf $=$ trifluoromethanesulfonate), obtained in situ from reaction of $2 a-c$ and $4 a-c$ with AgOTf, react with a number of alkenes. Nonstrained alkenes do insert, but decomposition (probably involving $\beta$-elimination) is fast. Alkenes containing potential donor groups do not insert at all. Only in the case of strained alkenes like norbornene and its derivatives were the insertion products isolated and fully characterized by ${ }^{13} \mathrm{C} N \mathrm{NR}$, IR, and X-ray analysis. Crystals of the dicyclopentadiene insertion product $\left[\mathrm{Pd}\left(\mathrm{C}_{10} \mathrm{H}_{12} \mathrm{COMe}\right)(\mathrm{bpy})\right] \mathrm{OTf}(8 \mathrm{c})$ are monoclinic, space group $P 21 / n, a=$ 8.3086(4) $\AA, b=15.3894(6) \AA, c=18.1479(9) \AA, \beta=99.98(1)^{\circ}, V=2285.36(19) \AA^{3}, Z=4, R=0.042(w R=$ $0.034)$. Here, the alkene insertion has occurred in cis,exo fashion on the norbornene-type alkene moiety, indicating this reaction to be both stereo- and chemoselective. The molecular structure shows that the acyl group is coordinated to the metal. Products resulting from a second $\mathrm{CO}$ insertion into the $\mathrm{Pd}-\mathrm{C}$ bond of $8 \mathrm{a}$, i.e. $\mathrm{PdX}\left(\mathrm{COC}_{7} \mathrm{H}_{10} \mathrm{COMe}\right)-$ (bpy) $(\mathrm{X}=\mathrm{Cl}(\mathbf{1 2 a})$ or I (12b)), were formed in the presence of a large excess of a sodium halide salt. Reaction of 12a,b with AgOTf and norbornene gave the alkyl complex $\left[\mathrm{Pd}\left(\mathrm{C}_{7} \mathrm{H}_{10} \mathrm{COC}_{7} \mathrm{H}_{10} \mathrm{COMe}\right)(\mathrm{bpy})\right] \mathrm{OTf}$ (13a). Norbornadiene was inserted similarly. Attempted recrystallization of the insertion product of 5-norbornene-endo2,3-dicarboxylic anhydride (13c) gave the alkyl complex 8a. This is the first example of a reversible alkene insertion reaction on an isolated palladium complex. Addition of $\mathrm{CO}$ and excess $\mathrm{NaI}$ (20 equiv) to 13a gave the neutral acyl complex PdI $\left(\mathrm{COC}_{7} \mathrm{H}_{10} \mathrm{COC}_{7} \mathrm{H}_{10} \mathrm{COMe}\right)$ (bpy) (14), the first isolated and fully characterized $\mathrm{CO} /$ alkene oligomer still connected to the palladium(II) catalytic site. Crystals are triclinic, space group $P \overline{1}$ with $a=10.128(2) \AA, b=$ 11.655(2) $\AA, c=13.633(2) \AA, \alpha=109.89(1)^{\circ}, \beta=100.58(1)^{\circ}, \gamma=92.92(2)^{\circ}, V=1476.3(4) \AA^{3}, Z=2$ and $R=$ $0.044(w R=0.057)$. Norbornadiene also reacts with 2 equiv. of 5 or 6 to give the homoligated dinuclear complexes $\left[(\mathrm{N}-\mathrm{N}) \mathrm{Pd}\left\{\left(\mathrm{C}_{7} \mathrm{H}_{8}\right)(\mathrm{COMe})_{2}-2,5\right\} \mathrm{Pd}(\mathrm{N}-\mathrm{N})\right](\mathrm{OTf})_{2}$ with $\mathrm{N}-\mathrm{N}=$ tmeda $(9)$ or bpy $(10)$. Crystals of 9 are orthorhombic, space group $P 2{ }_{1} 2_{1} 2_{1}, a=11.176(3) \AA, b=11.362$ (1) $\AA, c=30.394$ (3) $\AA, V=3859$ (1) $\AA^{3}, Z=4, w R 2=0.124$, $R=0.049$. In this complex a double alkene insertion reaction has taken place involving both alkene functionalities of a dialkene: 9 is symmetrically substituted with the Pd atoms at opposite (trans) positions.
\end{abstract}

\section{Introduction}

The insertion of unsaturated molecules into metal-carbon bonds is a key step in metal-mediated synthesis and catalysis. ${ }^{1}$ Currently, much interest is devoted to alkoxycarbonylation of alkenes $^{2}$ and alkynes ${ }^{3}$ and, in particular, to the copolymerization of alkenes with carbon monoxide ${ }^{4,5}$ using palladium-based

* To whom correspondence should be addressed.

Debye Institute.

Bijvoet Center for Biomolecular Research.

$\$$ To whom correspondence concerning crystallographic data should be addressed.

* Abstract published in Advance ACS Abstracts, April 1, 1995.

(1) (a) Yamamoto, A. Organotransition Metal Chemistry; J. Wiley \& Sons: New York, 1986. (b) Chaloner, P. A. Handbook of Coordination Catalysis in Organic Chemistry; Butterworths: London, 1986.

(2) See, for example: (a) Milstein, D. Acc. Chem. Res. 1988, 21, 428.

(b) Cavinato, G.; Toniolo, L. J. Organomet. Chem. 1990, 398, 187. catalysts. The most favored mechanism of these copolymerization reactions contains two propagation steps: (1) $\mathrm{CO}$

(3) Drent, E.; Arnoldy, P.; Budzelaar, P. H. M. J. Organomet. Chem. 1993, 455, 247 and references cited therein

(4) For reviews, see: (a) Sen, A. Chemtech 1986, 48. (b) Sen, A. Adv. Polym. Sci. 1986, 73/74, 125. (c) Drent, E. Pure Appl. Chem. 1990, 62, 661. (d) Sen, A. Acc. Chem. Res. 1993, 26, 303.

(5) (a) Drent, E.; Van Broekhoven, J. A. M.; Doyle M. J. J. Organomet. Chem 1991, 417, 235. (b) Pisano, C.; Consiglio, G.; Sironi, A.; Moret, M. J. Chem. Soc., Chem. Common. 1991, 421. (c) Barsacchi, M.; Consiglio, G.; Medici, L.; Petrucci, G.; Suter, U. W. Angew. Chem., Int. Ed. Engl. 1991, 30, 989. (d) Batistini, A.; Consiglio, G.; Suter, U. W. Angew. Chem. Int. Ed. Engl. 1992, 31, 303. (e) Pisano, C.; Mezzetti, A.; Consiglio, G. Organometallics 1992, 11,20 . (f) Batistini, A.; Consiglio, G. Organometallics 1992, 11, 1766. (g) Pisano, C.; Nefkens, S. C. A.; Consiglio, G. Organometallics 1992, 11, 1975. (h) Dalcanale, E.; An, Z.; Battaglia, I. P.; Catellani, M.; Chiusoli, G. P. J. Organomet. Chem. 1992, 437, 375. (i) Jiang, Z.; Dahlen, G. M.; Houseknecht, K.; Sen, A. Macromolecules 1992. $25,2999$. 


\section{Scheme 1}

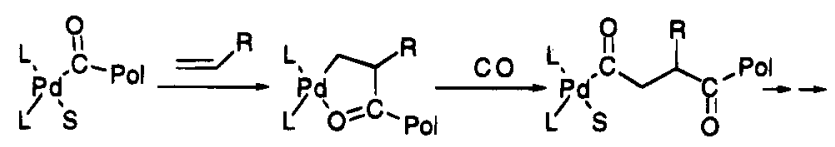

Pol $=$ polymer chain, $S=$ solvent or anion

migratory insertion into a Pd-alkyl bond and (2) alkene insertion into a Pd-acyl bond (Scheme 1), 4,5 Another mechanism, proposed by Consiglio et al. ${ }^{5 \mathrm{f}}$ invokes palladiumcarbene intermediates to account for the high stereoregularity of the copolymerization and the formation of a spiroketal structure instead of the linear polymer. This mechanism has gained little support so far. The second step in Scheme 1, i.e., the carbonylation of metal-alkyl complexes, has been the subject of many model studies, ${ }^{6-9}$ and two insertion mechanisms have been proposed. The most favored is a dissociative mechanism, in which one of the ligands is displaced by $\mathrm{CO}$ after which insertion from a four-coordinate intermediate occurs. Recent $a b$ initio calculations on ionic complexes containing nitrogen donor ligands suggest that $\mathrm{Pd}-\mathrm{N}$ bond dissociation might be assisted by coordination of $\mathrm{CO}$ to palladium in an apical position thus lowering the activation energy of this step. ${ }^{9 \mathrm{~d}}$ This leads to a four-coordinate intermediate in which migratory $\mathrm{CO}$ insertion takes place. The second mechanism is associative, i.e., $\mathrm{CO}$ adds as a fifth ligand to the metal followed by insertion.

In contrast, studies of the first step in Scheme 1, i.e., the insertion of alkenes into the palladium-acyl bond, are relatively

(6) For reviews, see: (a) Calderazzo, F. Angew. Chem. 1977, 89, 305. (b) Kuhlmann, E. J.; Alexander, J. J. Coord. Chem. Rev. 1980, 33, 195. (c) Anderson, G. K.; Cross, R. J. Acc. Chem. Res. 1984, 17, 67. For recent articles see refs $7-9$.

(7) For complexes of monodentate P-donors, see: (a) Huser, M; Youinou, M.-T.; Osborn, J. A. Angew. Chem., Int. Ed. Engl. 1989, 28, 1386. (b) Ozawa, F.; Son, T.-i.; Osakada, K.; Yamamoto, A. J. Chem. Soc., Chem. Commun. 1989, 1067. (c) Dirè, S.; Campostrini, R.; Carturan, G.; Calligaris, M.; Nardin, G. J. Organomet. Chem. 1990, 390, 267. (d) Brumbaugh, J. S.; Whittle, R. R.; Parvez, M.; Sen, A. Organometallics 1990, 9, 1735. (e) Yamamoto, A.; Ozawa, F.; Osakada, K.; Huang, L.; Son, T.; Kawasaski, N.; Doh, M.-K. Pure Appl. Chem. 1991, 63, 687 and references therein. (f) Grushin, V; Alper, H. Organometallics 1993, 12, 1890

(8) For P-P complexes; see: (a) Ozawa, F.; Hayashi, T.; Koide, H.; Yamamoto, A. J. Chem. Soc., Chem. Commun. 1991, 1469. (b) Dekker, G. P. C. M.; Elsevier, C. J.; Vrieze, K.; van Leeuwen, P. W. N. M.; Roobeek C. F. J. Organomet. Chem. 1992, 430, 357. (c) Dekker, G. P. C. M. Elsevier, C. J.; Vrieze, K.; van Leeuwen, P. W. N. M. Organometallics 1992, 11,1598 . (d) Tóth. I.; Elsevier, C. J. J. Chem. Soc., Chem. Commun. 1993, 529. For P-N complexes, see: (e) Anderson, G. K.; Lumetta, G. J. Organometallics 1985, 4, 1542. (f) Dekker, G. P. C. M.; Buijs, A.; Elsevier, C. J.; Vrieze, K.; van Leeuwen, P. W. N. M.; Smeets, W. J. J.; Spek, A. L.; Wang, Y. F.; Stam, C. H. Organometallics 1992, 11, 1937. For $\mathrm{N}-\mathrm{N}$ complexes, see: (g) de Graaf, W.; Boersma, J.; van Koten, G. Organome tallics 1990, 9, 1479. (h) Markies, B. A.; Rietveld, M. H. P.; Boersma, J. Spek, A. L.; van Koten, G. J. Organomet. Chem. 1992, 424, C12. (i) Vrieze, K.; Dekker, G. P. C. M.; Elsevier, C. J.; Han, I. M.; van Leeuwen, P. W. N. M.; Rülke, R. E. VIIth International Symposium on Homogeneous Catalysis; Lyon-Villeurbanne, 1990. (j) Brookhart, M.; Rix, F. C. DeSimone, J. M. J. Am. Chem. Soc. 1992, 114, 5894. (k) van Asselt, R.; Gielens, E. E. C. G.; Rülke, R. E.; Elsevier, C. J. J. Chem. Soc., Chem. Commun. 1993, 1203. (1) Markies, B. A.; Verkerk, K. A. N.; Rietveld, M. H. P.; Boersma, J.; Kooijman, H.; Spek, A. L.; van Koten, G. J. Chem. Soc., Chem. Commun. 1993, 1317. (m) van Asselt, R.; Gielens, E. E. C. G.; Rülke, R. E.; Vrieze, K.; Elsevier, C. J. J. Am. Chem. Soc. 1994, 116, 977. Other ligands: (n) Anderson, G. K.; Lumetta, G. J. Organometallics 1985, 4, 1542. (o) Cavell, K. J.; Jin, H.; Skelton, B. W.; White, A. H. J. Chem. Soc., Dalton Trans. 1992, 2923. (p) Cavell, K. J.; Jin, H.; Skelton B. W.; White, A. H. J. Chem. Soc., Dalton Trans. 1993, 1973. (q) Lindner, E.; Dettinger, J.; Fawzi, R.; Steimann, M. Chem. Ber. 1993, 126, 1347. (r) Reger, D. L.; Garza, D. G. Organometallics 1993, 12, 554

(9) For N-N-N complexes, see: (a) Rülke, R. E.; Han, I. M.; Elsevier, C. J.; Vrieze, K.; van Leeuwen, P. W. N. M.; Roobeek, C. F.; Zoutberg, M. C.; Wang, Y. F.; Stam, C. H. Inorg. Chim. Acta 1990, 169, 5. (b) Markies, B. A.; Wijkens, P.; Boersma, J.; Spek, A. L.; van Koten, G. Recl. Trav. Chim. Pays-Bas 1991, 110, 133. (c) Vrieze, K.; Rülke, R. E.; van Leeuwen, P. W. N. M.; Elsevier, C. J. Euchem Conference; Alghero, 1992 (d) Markies, B. A.; Wijkens, P.; Dedieu, A.; Boersma, J.; Spek, A. L.; van Koten, G. J. Am. Chem. Soc., submitted for publication.

\section{Scheme 2}

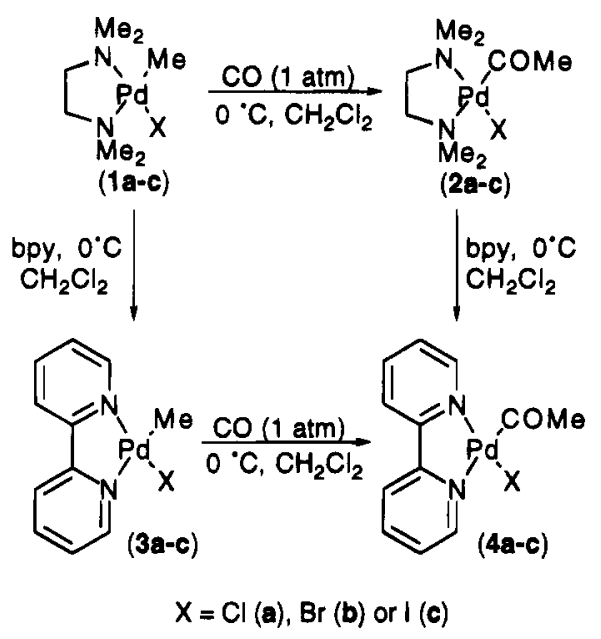

scarce $^{7 \mathrm{~d}, 8 \mathrm{a}, \mathrm{b}, \mathrm{h}-\mathrm{m}, 9 \mathrm{c}, 10}$ Generally, it is found that ionic complexes react more readily than neutral complexes with alkenes. This suggests that the presence of an easily accessible coordination site at the cationic metal center of the former is responsible. Sen $e t$ al. have shown that for both neutral and ionic monodentate phosphorus complexes insertion occurs from a fourcoordinate intermediate. ${ }^{4 d, 7 d}$ The most stable insertion products are obtained with strained alkenes, like norbornene and derivatives. Other alkenes also insert, but the insertion products rapidly decompose via $\beta$-elimination. . $^{\mathrm{b}}$

Although the CO/alkene copolymerization is well-known, ${ }^{4,5}$ little is known about the sequential insertion of alkenes and $\mathrm{CO}$ at a metal center. ${ }^{8 j-m}$ Brookhart et al. were able to observe the intermediate acyl complexes in the alternating insertion of 4-tert-butylstyrene and $\mathrm{CO}$ by ${ }^{13} \mathrm{C}$ NMR when $\left[\mathrm{B}\left(\mathrm{C}_{6} \mathrm{H}_{3}\left\{\mathrm{CF}_{3}\right\}_{2-}\right.\right.$ $\left.3,5)_{4}\right]^{-}$is used as the anion. ${ }^{8 j}$ Recently, Elsevier et al. reported the sequential insertion of $\mathrm{CO}$ and norbornadiene starting from PdCIMe(BIAN) (BIAN = bis(arylimino)acenaphthenes) to form the metal-bound oligomer $\mathrm{PdCl}\left(\mathrm{COC}_{7} \mathrm{H}_{8} \mathrm{COC}_{7} \mathrm{H}_{8} \mathrm{COMe}\right)(\mathrm{BIAN})$ and isolated the acyl and alkyl intermediates. ${ }^{8 k, m}$ Their method seems to be restricted to norbornadiene, as other strained alkenes like norbornene and dicyclopentadiene give only incomplete insertion into the $\mathrm{Pd}-\mathrm{C}$ (acyl) bond.

In the present paper we describe the synthesis of acetylpalladium(II) complexes and report a study of an isomerization process occurring in these complexes. We have extended the range of alkenes which can be inserted into both neutral and ionic acyl complexes containing bidentate nitrogen donor ligands, and we report in more detail on the stepwise and stereoregular construction of $\mathrm{CO} /$ alkene co-oligomers on a palladium(II) center as well as the structural details of the first isolated and fully characterized CO/alkene oligomer still connected to the PdI catalytic site. Preliminary reports of this work have appeared. ${ }^{8 h, 1}$

\section{Results}

Synthesis and Properties of Acetyl Complexes. Based on the method found by de Graaf et al., ${ }^{8 g}$ the complexes PdX(COMe)(bpy), with $\mathrm{X}=\mathrm{Cl}(\mathbf{4 a}),{ }^{11} \mathrm{Br}(\mathbf{4 b})$, or I $(\mathbf{4 c})$, were obtained via two routes from $\mathrm{PdXMe}(\mathrm{tmeda})(\mathbf{1 a}-\mathbf{c})$ as presented in Scheme 2. The overall yield is ca. 85\%, independent of the halide and the route followed. Both the tmeda $(\mathbf{2 a}-\mathbf{c})$ and bpy $(\mathbf{4 a}-\mathbf{c})$ acetyl complexes are surprisingly stable, and they can be kept at room temperature in air for

(10) Markies, B. A.; Wijkens, P.; Kooijman, H.; Spek, A. L.; Boersma J.; van Koten, G. J. Chem. Soc., Chem. Commun. 1992, 1420

(11) An X-ray crystal structure of $\mathbf{4 a}$ has been determined. Rülke, R. E.; Elsevier, C. J.; Vrieze, K., unpublished results. 
Table 1. Activation and Thermodynamical Parameters of the Isomerization of $\mathbf{4 a - c}$

\begin{tabular}{|c|c|c|c|c|c|c|}
\hline $\mathrm{mr}$ & nt & $\ln A$ & $\begin{array}{c}\begin{array}{c}E_{\text {act, }} \\
\text { kcal } \\
\mathrm{mol}^{-1}\end{array} \\
\end{array}$ & $\begin{array}{c}\Delta H^{\ddagger} \\
\mathrm{kcal} \\
\mathrm{mol}^{-1}\end{array}$ & $\begin{array}{c}\Delta S^{+}, \\
\mathrm{cal}^{\prime} \\
\mathrm{mol}^{-1}\end{array}$ & $\begin{array}{c}\Delta G^{\ddagger}{ }_{298}, \\
\mathrm{kcal} \\
\mathrm{mol}^{-1}\end{array}$ \\
\hline $4 \mathbf{a}$ & $\begin{array}{l}\mathrm{CDCl}_{3} \\
\mathrm{CD}_{3} \mathrm{COCD}_{3} \\
\mathrm{CDCl}_{3} \\
\mathrm{CD}_{3} \mathrm{COCD}_{3} \\
\mathrm{CDCl}_{3}\end{array}$ & & & $\begin{array}{r}9 \pm \\
17 \pm \\
10 \pm \\
17 \pm\end{array}$ & $\begin{array}{r}-14 \pm 2 \\
-29 \pm 1 \\
-1 \pm 2 \\
-24 \pm 4 \\
1 \pm 7\end{array}$ & $\begin{array}{l}17 \pm 2 \\
17 \pm 4\end{array}$ \\
\hline
\end{tabular}

several months without decomposition. In solution $\left(\mathrm{CDCl}_{3}\right.$ or $\mathrm{CD}_{3} \mathrm{COCD}_{3}$ ) the complexes are less stable, but these solutions remain unchanged for a few days when stored at $-20^{\circ} \mathrm{C}$. The complexes PdXMe(bpy) $(3 \mathbf{a}-\mathbf{c})$ were identical to those obtained by Byers and Canty via another route. ${ }^{12}$

The bpy-H6 and $-\mathrm{H}^{\prime}$ NMR resonances of $4 \mathrm{a}-\mathrm{c}$ are very sensitive to the ligand which is in the cis position at the metal center, i.e., either the halide anion or the metal group, and can therefore be readily assigned like those of $\mathbf{3 a}-\mathbf{c}$. We observed that, when the $\mathrm{H} 6$ proton next to the halide is irradiated, the resonance of $\mathrm{H}^{\prime}$ also disappears and vice versa. This can be explained by fast spin transfer between these two nuclei caused by exchange of coordination positions on the NMR time scale, i.e., an isomerization of the acetyl complexes, see eq 1 :<smiles></smiles><smiles></smiles>

Similar observations were reported by van Asselt et al. ${ }^{13}$ No such effects were found in the methyl complexes 3a-c. Spin saturation transfer measurements using the Forsén-Hoffman method $^{14}$ allowed the determination of the thermodynamic parameters of the isomerization of $\mathbf{4 a - c}$ (Table 1). Unfortunately, $\mathrm{PdI}(\mathrm{COMe})(\mathrm{bpy})(\mathbf{4 c})$ is only slightly soluble in $\mathrm{CDCl}_{3}$, leading to large errors for this solvent, while in acetone the low solubility of $4 \mathrm{c}$ did not allow ${ }^{1} \mathrm{H}$ NMR experiments at all. The other two complexes $(\mathbf{4 a}, \mathbf{b})$ were soluble in both solvents. The neutral acetyl complexes 2 and 4 can be readily and quantitatively converted to their ionic analogs $[\mathrm{Pd}(\mathrm{COMe})(\mathrm{MeCN})(\mathrm{N}$ $\mathrm{N})$ ]OTf, with $\mathrm{N}-\mathrm{N}=$ tmeda $(5)$ or bpy (6), by reacting them with silver trifluoromethanesulfonate (AgOTf, Scheme 4). These complexes are, however, unstable and do not allow characterization.

Alkene Insertion into Pd-COMe Bonds. The neutral complexes $\mathrm{PdX}(\mathrm{COMe})(\mathrm{N}-\mathrm{N})(\mathbf{2 a}, \mathrm{c}$ and $\mathbf{4 a}, \mathrm{c})$ were reacted with norbornene and norbornadiene at room temperature, and the reactions (Scheme 3 ) were monitored by NMR in either $\mathrm{CD}_{3}$ $\mathrm{COCD}_{3}$ or $\mathrm{CDCl}_{3}$. The insertion of norbornadiene into the $\mathrm{Pd}-$ $\mathrm{C}$ (acyl) bond of $\mathbf{4 c}$ was very fast $(<5 \mathrm{~min})$ in both solvents but was much slower in $\mathrm{CD}_{3} \mathrm{COCD}_{3}(30 \mathrm{~min})$ than in $\mathrm{CDCl}_{3}(10$ min) for $4 \mathbf{a}$. Similar observations were obtained in $\mathrm{CDCl}_{3}$ for 2a $(80 \%$ in $45 \mathrm{~min})$ and $2 \mathrm{c}(100 \%$ in $8 \mathrm{~min})$. Norbornene was found to react very differently from norbornadiene. The tmeda complexes 2a,c did not react with norbornene in either of the two solvents. The bpy complexes $4 a, c$ were only reactive

(12) Byers, P. K.; Canty, A. J. Organometallics 1990, 9, 210.

(13) van Asselt, R. Synthesis, Reactivity and Catalytic Applications of Palladium and Platinum Complexes Containing Rigid Bidentate Nitrogen Ligands; Dutch Ph.D. Thesis, Amsterdam, 1993

(14) Mann, B. E. J. Magn. Reson. 1976, 21,17 and references therein
Scheme 3

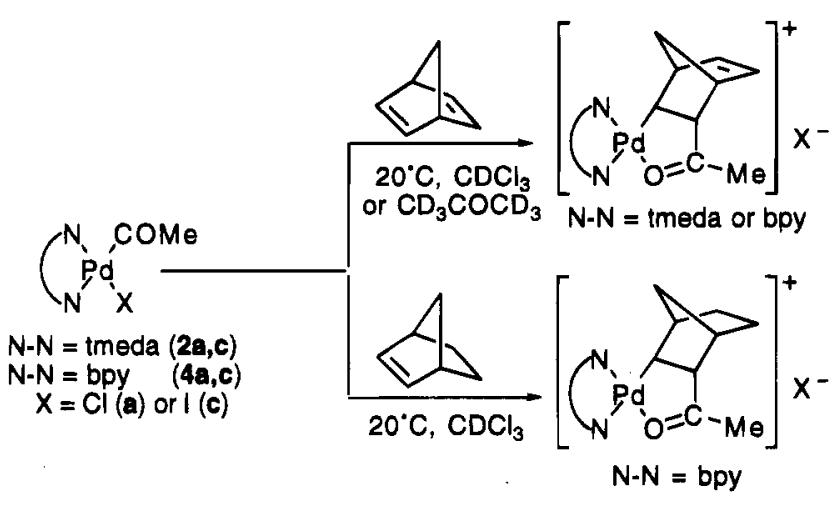

toward norbornene in $\mathrm{CDCl}_{3}$ giving $16 \%$ conversion in $90 \mathrm{~min}$ (4a) and $50 \%$ conversion in $60 \mathrm{~min}(4 \mathrm{~b})$, respectively. No insertion of norbornene was observed in acetone. Unfortunately, the neutral alkene insertion products are all unstable and decomposed significantly during the NMR experiments.

The ionic complexes $[\mathrm{Pd}(\mathrm{COMe})(\mathrm{MeCN})(\mathrm{N}-\mathrm{N})] \mathrm{OTf}(\mathbf{5}, \mathbf{6})$ are much more reactive toward alkenes (Scheme 4). Complex $5(\mathrm{~N}-\mathrm{N}=$ tmeda), prepared in situ, was reacted with norbornene, norbornadiene, dicyclopentadiene, and $\alpha$-methylstyrene. The latter alkene did not insert, but the other insertion products $(\mathbf{7 a}-$ c) were isolated in good yield and were characterized by NMR and IR (Table 2). The norbornadiene insertion product $(7 \mathbf{b})$ could not be obtained pure as samples always contained some of the homoligated dinuclear complex [(tmeda) $\mathrm{Pd}\left\{(\mathrm{MeCO})_{2}-\right.$ $\left.\mathrm{C}_{7} \mathrm{H}_{8}\right\} \mathrm{Pd}$ (tmeda)](OTf $)_{2}(9)$, which was prepared independently (vide infra). The scope of the alkene-insertion reaction was investigated for $[\mathrm{Pd}(\mathrm{COMe})(\mathrm{MeCN})(\mathrm{bpy})] \mathrm{OTf}(6)$. Four categories of alkenes were used: (i) the strained alkenes norbornene, norbornadiene, dicyclopentadiene, 5-norbornene-endo2,3-dicarboxylic anhydride, and 7-oxa-5-norbornene-exo-2,3dicarboxylic anhydride; (ii) the nonstrained alkenes styrene, cyclopentene, cyclohexene, cycloheptene, ethylene; (iii) the nonstrained alkenes containing a potential donor atom 2-vinylpyridine and 2,3-dihydrofuran; and (iv) the nonstrained alkenes containing electron withdrawing substituents, methyl methacrylate, benzylideneacetone, methyl vinyl ketone, and maleic anhydride. Only the strained alkenes of type (i) insert to give stable products $(\mathbf{8 a}-\mathbf{e}$, Scheme 4$)$ which are readily isolable in good yield. These products were characterized by NMR and IR (Table 2). 8c was identified by X-ray analysis (vide infra). The type (ii) and (iv) alkenes styrene, cyclopentene, cyclohexene, cycloheptene, ethylene, methyl methacrylate, and methyl vinyl ketone did insert, as shown by the characteristic $v(\mathrm{C}-\mathrm{O})$ of the insertion products (Table 2 ), but these products could not be isolated pure and were very unstable in solution even at lower temperature $\left(-20^{\circ} \mathrm{C}\right)$. The other alkenes, i.e., 2-vinylpyridine, benzylideneacetone, 2,3-dihydrofuran, and maleic anhydride, did not give insertion products observable by ${ }^{1} \mathrm{H}$ NMR or IR spectroscopy.

The carbonyl stretching frequencies $v(C-O)$ for $7 \mathbf{a}-\mathbf{c}$ and $8 a-e$ have in all cases rather low values of $c a .1590-1600$ $\mathrm{cm}^{-1}$ (Table 2) which are attributed to coordination of the oxygen atom of the ketone to the metal. Similarly, the ${ }^{13} \mathrm{C}$ NMR resonances are significantly shifted to lower field (ca. $240 \mathrm{ppm}$, Table 2) with respect to those of normal organic ketones. This is also caused by ketone coordination because palladium induces low-field shifts of the resonances of nuclei close to the metal.

The ${ }^{1} \mathrm{H}$ NMR spectra of the dicyclopentadiene insertion products $7 \mathrm{c}$ and $8 \mathrm{c}$ indicate that only the strained norbornenetype double bond is involved in the insertion. This was further substantiated by the X-ray structure of $8 \mathrm{c}$ (vide infra). The unreacted double bond of $7 \mathrm{c}$ and $8 \mathrm{c}$ appears as two sets of ${ }^{1} \mathrm{H}$ 
Scheme 4
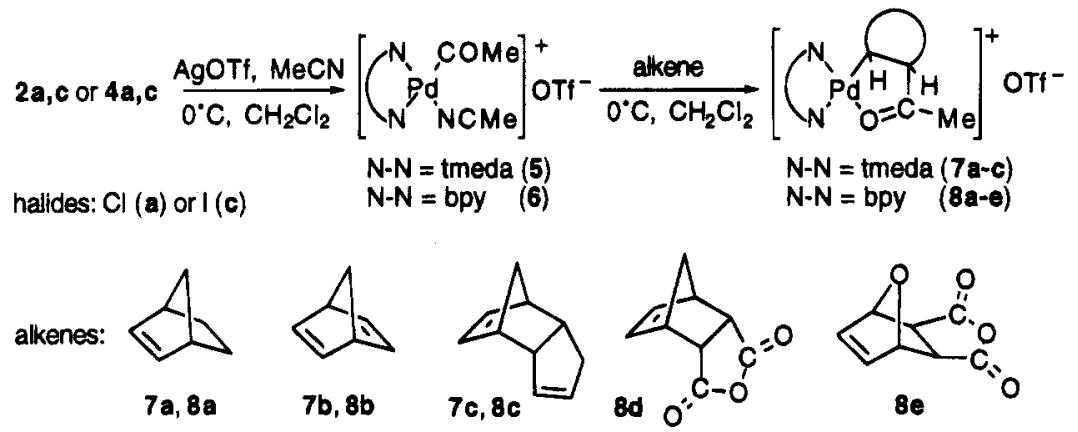

NMR resonances in a 1:1.1 (7c) and a 1:1.7 (8c) ratio because in each case two regioisomers form in unequal amounts upon insertion.

Double Insertion. When norbornadiene is reacted with 2 equiv of the ionic acetyl complexes $[\mathrm{Pd}(\mathrm{COMe})(\mathrm{MeCN})(\mathrm{N}-\mathrm{N})]-$ OTf (5 or 6), prepared in situ, the homoligated dinuclear complexes $\left[(\mathrm{N}-\mathrm{N}) \mathrm{Pd}-\left\{\mathrm{C}_{7} \mathrm{H}_{8}(\mathrm{COMe})_{2}-2,5\right\} \mathrm{Pd}(\mathrm{N}-\mathrm{N})\right](\mathrm{OTf})_{2}$ are obtained in moderate yields (eq 2), i.e., $49 \%(9, \mathrm{~N}-\mathrm{N}=$ tmeda, always present as impurity in $7 \mathrm{~b})$ and $47 \%(10, \mathrm{~N}-\mathrm{N}=$ bpy).

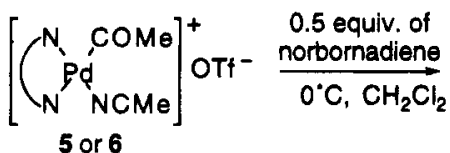

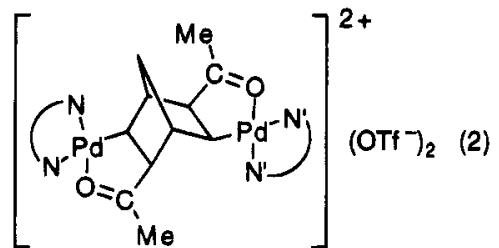

$$
\begin{aligned}
& N-N=N^{\prime}-N^{\prime}=\text { tmeda } \\
& N-N=N^{\prime}-N^{\prime}=b p y \\
& N-N=\text { tmeda, } N^{\prime}-N^{\prime}=\text { bpy }(11)
\end{aligned}
$$

Complex 10 was slightly soluble only in acetonitrile. The IR and NMR spectra (Table 2) of 9, before and after purification, indicate that the complex has $C_{2}$ symmetry, i.e., addition of the second palladium center occurs trans to the first. This is corroborated by the molecular structure of this complex (vide infra). The heteroligated dinuclear complex [(bpy) $\mathrm{Pd}\left\{\mathrm{C}_{7} \mathrm{H}_{8}\right.$ $\left.\left.(\mathrm{COMe})_{2}-2,5\right\} \mathrm{Pd}(\mathrm{tmeda})\right](\mathrm{OTf})_{2}$ (11) was best obtained by reacting $\left[\mathrm{Pd}\left(\mathrm{C}_{7} \mathrm{H}_{8} \mathrm{COMe}\right)(\mathrm{bpy})\right] \mathrm{OTf}(\mathbf{8 b})$ with 1 equiv of, in situ prepared, $[\mathrm{Pd}(\mathrm{COMe})(\mathrm{MeCN})($ tmeda) $]$ OTf (5). This complex is, however, very unstable both in solution and in the solid state, allowing only characterization by IR (Table 2 ).

Molecular Structures of the Cations [Pd( $\left.\mathrm{C}_{10} \mathrm{H}_{12} \mathrm{COMe}\right)$ (bpy) $]^{+}$(8c) and [(tmeda)Pd $\left\{\mathrm{C}_{7} \mathrm{H}_{8}(\mathrm{COMe})_{2}-2,5\right\} \mathrm{Pd}(\mathrm{tme}-$ da) $]^{2+}(9)$. ORTEP representations of the cations of $8 c^{8 \mathrm{~h}}$ and 9 are presented in Figures 1 and 2, respectively, with selected bond distances and angles in Table 3 . The molecular structure of the cation of 8c (Figure 1) shows the carbonyl group to be coordinated to the metal $(\mathrm{Pd}-\mathrm{O}=2.026(3) \AA)$ resulting in the formation of a five-membered PdCCCO chelate ring. The palladium center in $\mathbf{8 c}$ has a square planar geometry involving the $\mathrm{C}, \mathrm{O}$-chelate bonded ligand and the 2,2'-bipyridyl ligand. The Pd-C11 distance of the C,O-chelate bonded ligand (2.023(4) $\AA$ ) is comparable to those found for other palladium-bound $\mathrm{sp}^{3}$-carbons trans to a $\mathrm{sp}^{2}$-nitrogen atom $(2.036(6) \AA) .{ }^{8 \mathrm{~h}, 1,9 \mathrm{a}, \mathrm{b}, 15}$ The $\mathrm{C} 21-\mathrm{O} 1$ bond distance $(1.249(6) \AA)$ is normal for a noncoordinated carbonyl group. The molecular structure clearly shows that the dicyclopentadiene moiety has selectively reacted, on the exo face, with the 5,6-double bond rather than with the 2,3-double bond. This exo-mode of insertion is consistent with
Table 2. Selected ${ }^{13} \mathrm{C}$ NMR and IR Data of the Alkene Insertion Products

\begin{tabular}{ccl}
\hline complex & $\nu(\mathrm{C}-\mathrm{O}), \mathrm{cm}^{-1}$ & \multicolumn{1}{c}{$\delta, \mathrm{ppm}$} \\
\hline $\mathbf{7 a}$ & 1599 & 238.70 \\
$\mathbf{7 b}$ & 1607 & 239.28 \\
$\mathbf{7 c}$ & 1605 & $239.16 / 240.77$ \\
$\mathbf{8 a}$ & 1601 & 240.83 \\
$\mathbf{8 b}$ & 1603 & 239.00 \\
$\mathbf{8 c}$ & 1603 & $243.45 / 244.68$ \\
$\mathbf{8 d}$ & 1604 & 242.75 \\
$\mathbf{8 e}$ & 1612 & 239.54 \\
$\mathbf{9}$ & 1595 & 238.62 \\
$\mathbf{1 0}$ & 1601 & $a$ \\
$\mathbf{1 1}$ & 1606 & $b$
\end{tabular}

${ }^{a}$ Not determined due to low solubility. ${ }^{b}$ Not determined due to fast decomposition.

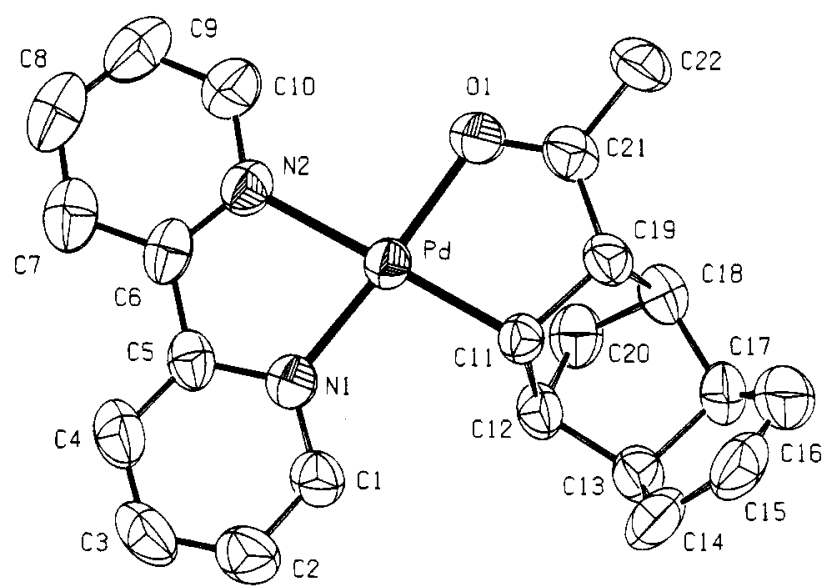

Figure 1. ORTEP plot (50\% probability level) of the structure of the cation of $\left[\mathrm{Pd}\left(\mathrm{C}_{10} \mathrm{H}_{12} \mathrm{COMe}\right)(\right.$ bpy $\left.)\right]$ OTf $(\mathbf{8 c})$.

the results of Sen et al., who showed that insertion of norbornene in trans- $\left[\mathrm{Pd}(\mathrm{COMe})(\mathrm{MeCN})\left(\mathrm{PPh}_{3}\right)_{2}\right] \mathrm{BF}_{4}$ also takes place on the exo face of the norbornene moiety. ${ }^{7 \mathrm{~d}}$ The fact that the observed bond distances for $\mathrm{C} 14-\mathrm{C} 15(1.425(9) \AA)$ and $\mathrm{C} 15-\mathrm{C} 16$ (1.391(9) Å) differ only slightly, with values in between a single and a double bond, suggests that these bond distances are the average of the distances of the two isomers (vide supra) present in the crystal. The molecular structure of the cation of 9 (Figure 2) clearly shows the $C_{2}$ symmetric addition of the two PdCOMe moieties on the two double bonds of norbornadiene. The structural features of this cation are similar to those of $8 \mathrm{c}$, except that the $\mathrm{Pd}-\mathrm{N}$ bonds are significantly longer. The $\mathrm{Pd}-\mathrm{O}$ bond distances of $9(2.016(5)$ and $2.033(5) \AA)$ and $8 c(2.026(3) \AA)$ are approximately the same, which is consistent with the comparable trans-influence of a tertiary amino and a pyridylimino group.

Sequential Insertion of $\mathrm{CO}$ and Alkenes. After the insertion of an alkene into the $\mathrm{Pd}-\mathrm{C}$ bond of the acetyl complexes a new Pd-alkyl bond is obtained. This should, in 


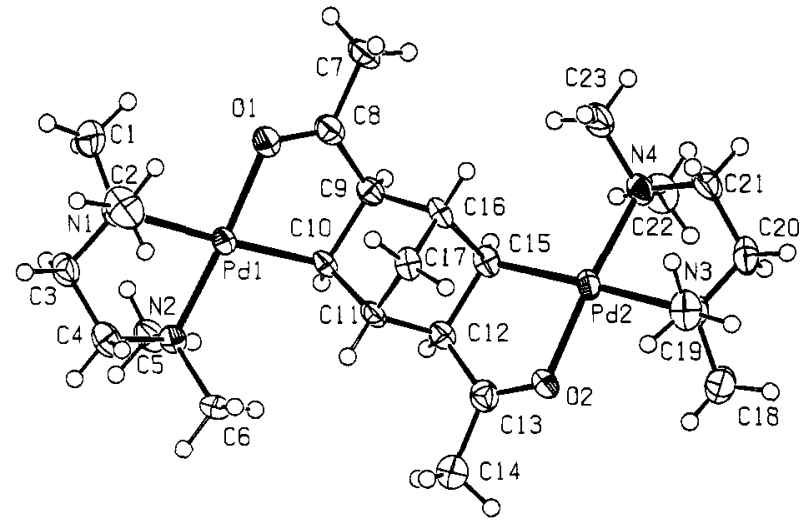

Figure 2. ORTEP plot (50\% probability level) of the structure of the cation of $\left[(\right.$ tmeda $\left.) \mathrm{Pd}\left\{\mathrm{C}_{7} \mathrm{H}_{8}(\mathrm{COMe})_{2}-2,5\right\} \mathrm{Pd}(\mathrm{tmeda})\right](\mathrm{OTf})_{2}$ (9).

Scheme 5

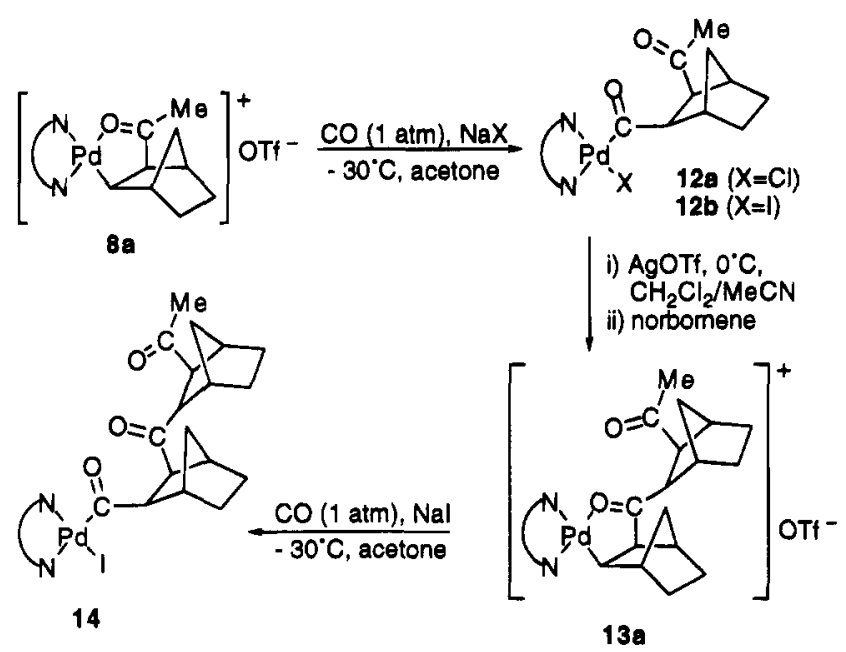

principle, allow the insertion of another molecule of $\mathrm{CO}$ into the $\mathrm{Pd}-\mathrm{C}($ alkyl) bond like in the methyl complexes. Initial attempts to insert $\mathrm{CO}$ at low or high pressure (at 1 or at 40 atm) into the $\mathrm{Pd}-\mathrm{C}\left(\right.$ alkyl) bond of $\left[\mathrm{Pd}\left(\mathrm{C}_{7} \mathrm{H}_{10} \mathrm{COMe}\right)(\mathrm{bpy})\right] \mathrm{OTf}$ (8a) did not give an isolable acyl complex. This suggests that either the insertion does not take place or that the reaction is reversible and that, upon attempted isolation, the complex deinserts $\mathrm{CO}$. The latter conclusion agrees with the results of van Leeuwen et al., who studied the bidentate phosphine complexes $[\mathrm{Pd}(\mathrm{COMe})(\mathrm{MeCN})(\mathrm{dppp})] \mathrm{OTf}$ and $\mathrm{PdCl}(\mathrm{COMe})-$ (dppp) (dppp $=1,3$-bis (diphenylphosphino)propane). ${ }^{8 \mathrm{~b}}$ These complexes require the presence of a $\mathrm{CO}$ atmosphere during the reaction with norbornene due to the instability of both the neutral and the ionic acetyl complex toward decarbonylation. The reaction of norbornene with the neutral complex gave the expected alkene insertion product, but also a secondary product that was suggested to result from a subsequent $\mathrm{CO}$ insertion yielding a new acyl complex. The same reaction with the ionic acetyl complex showed only the alkene insertion product. These results do suggest that the presence of a strongly coordinating anion is necessary to enable the isolation of an acyl complex. Indeed, by adding a large excess of a sodium halide, i.e., at least 20 equiv excess of either $\mathrm{NaCl}$ or $\mathrm{NaI}$, prior to $\mathrm{CO}$ addition to $\left[\mathrm{Pd}\left(\mathrm{C}_{7} \mathrm{H}_{10} \mathrm{COMe}\right)(\mathrm{bpy})\right] \mathrm{OTf}$ (8a, Scheme 5), we were able to obtain the neutral acyl complexes $\mathrm{PdX}\left(\mathrm{COC}_{7} \mathrm{H}_{10} \mathrm{COMe}\right)$ (bpy), with $\mathrm{X}=\mathrm{Cl}(\mathbf{1 2 a})$ or I (12b), in excellent yields (83 and $93 \%$, respectively). As an alternative to the synthesis described above, $12 \mathrm{~b}(\mathrm{X}=\mathrm{I})$ could also be obtained by reacting $12 \mathrm{a}(\mathrm{X}=\mathrm{Cl})$ with 4 equiv of sodium iodide in acetone. Isomerization of 12a,b, similar to $4 \mathbf{a}-\mathbf{c}$, was not observed when either the bpy$\mathrm{H} 6$ or the bpy- $\mathrm{H}^{\prime}$ resonance was irradiated. The palladium- bound carbonyl groups have IR absorptions and ${ }^{13} \mathrm{C}$ NMR shifts (Table 4) that are normal for acylpalladium(II) compounds. ${ }^{6-9,10}$

Having found the correct conditions for both insertion of norbornene into acyl complex $4 a$ (to afford alkyl complex $8 a$ ) and for the further reaction of $8 \mathbf{a}$ with carbon monoxide to give the doubly $\mathrm{CO}$ inserted products $12 \mathbf{a}, \mathbf{b}$, the next step is to attempt a second insertion of norbornene. This was successfully accomplished, analogously to the synthesis of $\mathbf{8 a}$, by reacting either $12 \mathbf{a}$ or $12 b$ first with silver trifluoromethanesulfonate (AgOTf) and then with norbornene (Scheme 5), thus affording complex 13a in $98 \%$ yield. This complex contains two carbonyl and two cis,exo substituted norbornyl fragments and shows the characteristic low frequency infrared stretching vibration at 1582 $\mathrm{cm}^{-1}$ of a carbonyl group coordinating to palladium ( $c f .8 \mathrm{c}$, $1598 \mathrm{~cm}^{-1}$ ). The IR absorption of the other carbonyl group is at $1708 \mathrm{~cm}^{-1}$, a normal value for a free carbonyl group. The ${ }^{13} \mathrm{C}$ NMR resonances of the carbonyl carbon atoms of 13a have characteristic positions, i.e., $243.4 \mathrm{ppm}$ for the one coordinated $v i a$ its oxygen atom to the metal (cf. 240.8 for 8c) and 208.0 ppm for the other. Both the IR and ${ }^{13} \mathrm{C}$ NMR spectra (Table 4) of complex 13a clearly show that the structure is comparable to those of the single alkene inserted products $8 \mathbf{a}-\mathbf{e}$ (Table 2). Whether the two norbornyl units have adopted syn or anti positions could not be inferred from the NMR spectra.

Both norbornadiene and 5-norbornene-endo-2,3-dicarboxylic anhydride may also be inserted in the second alkene insertion step to give the insertion products $13 \mathrm{~b}$ and $13 \mathrm{c}$, respectively, both of which could not be obtained analytically pure. Nevertheless, satisfactory NMR and IR spectra could be obtained for $\mathbf{1 3 b}$. Surprisingly, an attempt to recrystallize $13 \mathrm{c}$ resulted in the formation of $\mathbf{8 a},{ }^{16}$ whereas nonpurified $\mathbf{1 3 c}$ gave an IR spectrum (Table 4) that unambiguously showed the presence of the insertion product. Even though the ${ }^{1} \mathrm{H}$ NMR spectrum of impure $13 \mathrm{c}$ was very complex and did not allow proper analysis, no resonances corresponding to either $8 \mathbf{a}$ or $12 \mathbf{a}$ were present.

Starting from complex 13a a further successful insertion of carbon monoxide was accomplished, in the presence of 20 equiv of sodium iodide, yielding the neutral acyl complex 14 (Scheme 5 ) in $88 \%$ yield. Recrystallization from acetone gave crystals suitable for an X-ray structural analysis (vide infra). The carbonyl groups are again found at characteristic positions in the IR and ${ }^{13} \mathrm{C}$ NMR spectra (Table 4).

Molecular Structure of the Complex $\mathrm{PdI}\left(\mathrm{COC}_{7} \mathrm{H}_{10}\right.$ $\mathrm{COC}_{7} \mathrm{H}_{10} \mathrm{COMe}$ )(bpy) (14). ${ }^{81}$ The asymmetric unit of the crystal structure contains one molecule of 14 together with one acetone solvent molecule. In the molecular structure of $\mathbf{1 4}$ (Figure 3, Table 5), the metal has a slightly distorted squareplanar surrounding consisting of a bidentate $\mathrm{N}$-bonded bpy ligand (N1, N2), an iodine atom (I), and a C-bonded acyl group (C11). In addition to the expected angular deviations resulting from the five-membered chelate ring $\left(\mathrm{N} 1-\mathrm{Pd}-\mathrm{N} 2=77.8(2)^{\circ}\right)$, the most noticeable distortion around the metal center is concerned with the position of the iodine atom, which lies 0.339 (1) A above the coordination plane defined by Pd, N1, N2, and

(15) (a) Byers, P. K.; Canty, A. J.; Skelton, B. W.; White, A. H. Organometallics 1990, 9, 826. (b) Markies, B. A.; Canty, A. J.; Janssen, M. D.; Spek, A. L.; Boersma, J.; van Koten, G. Recl. Trav. Chim. PaysBas 1991, 110, 477. (c) Canty, A. J.; Traill, P. R.; Skelton, B. W.; White, A. H. J. Organomet. Chem. 1992, 433, 213. (d) Byers, P. K.; Canty, A. J.; Skelton, B. W.; Traill, P. R.; Watson, A. A.; White, A. H. Organometallics 1992, $I 1,3085$.

(16) The molecular structure of $\mathbf{8 a}$ has also been determined. This complex shows properties similar to $8 \mathrm{c}$. Crystals were obtained from the deinsertion of the alkene from 13c during recrystallization from methanol/ diethyl ether, but they can also be conveniently obtained via direct crystallization of $\mathbf{8 a}$ from this solvent combination. See: Spek, A. L.; Markies, B. A.; Kruis, D.; Boersma, J.; van Koten, G. Acta Crystallogr., in press. 
Table 3. Selected Bond Distances $(\AA)$ and Angles (deg) of $\left[\mathrm{Pd}\left(\mathrm{C}_{10} \mathrm{H}_{12} \mathrm{COMe}\right)(\mathrm{bpy})\right] \mathrm{OTf}(8 \mathrm{c})$ and of $\left[\right.$ (tmeda) $\mathrm{Pd}\left\{\mathrm{C}_{7} \mathrm{H}_{8}(\mathrm{COMe})_{2}-2,5\right\}-\mathrm{Pd}($ tmeda $\left.)\right](\mathrm{OTf})_{2}(9)$

\begin{tabular}{|c|c|c|c|c|c|}
\hline \multicolumn{6}{|c|}{$\left[\mathrm{Pd}\left(\mathrm{C}_{10} \mathrm{H}_{12} \mathrm{COMe}\right)(\mathrm{bpy})\right] \mathrm{OTf}(\mathbf{8 c})$} \\
\hline $\begin{array}{l}\mathrm{Pd}-\mathrm{N} 1 \\
\mathrm{Pd}-\mathrm{N} 2\end{array}$ & $\begin{array}{l}2.013(3) \\
2.121(4)\end{array}$ & $\begin{array}{l}\mathrm{Pd}-\mathrm{C} 11 \\
\mathrm{Pd}-\mathrm{O} 1\end{array}$ & $\begin{array}{l}2.023(4) \\
2.026(3)\end{array}$ & $\mathrm{C} 21-\mathrm{O} 1$ & $1.249(6)$ \\
\hline $\begin{array}{l}\mathrm{O} 1-\mathrm{Pd}-\mathrm{N} 1 \\
\mathrm{O} 1-\mathrm{Pd}-\mathrm{N} 2 \\
\mathrm{O} 1-\mathrm{C} 21-\mathrm{C} 19\end{array}$ & $\begin{array}{c}175.94(13) \\
97.28(14) \\
119.4(4)\end{array}$ & $\begin{array}{l}\mathrm{O} 1-\mathrm{Pd}-\mathrm{C} 11 \\
\mathrm{~N} 1-\mathrm{Pd}-\mathrm{N} 2 \\
\mathrm{O} 1-\mathrm{C} 21-\mathrm{C} 22\end{array}$ & $\begin{array}{c}83.64(14) \\
79.50(15) \\
118.8(5)\end{array}$ & $\begin{array}{l}\mathrm{N} 1-\mathrm{Pd}-\mathrm{C} 11 \\
\mathrm{~N} 2-\mathrm{Pd}-\mathrm{C} 11 \\
\mathrm{C} 19-\mathrm{C} 21-\mathrm{C} 22\end{array}$ & $\begin{array}{l}99.69(15) \\
177.17(16) \\
121.8(4)\end{array}$ \\
\hline $\begin{array}{l}\mathrm{Pd} 1-\mathrm{N} 1 \\
\mathrm{Pd} 1-\mathrm{N} 2 \\
\mathrm{Pd} 2-\mathrm{N} 3 \\
\mathrm{Pd} 2-\mathrm{N} 4\end{array}$ & $\begin{array}{l}2.170(6) \\
2.083(5) \\
2.166(6) \\
2.053(5)\end{array}$ & $\begin{array}{l}\text { a) } \mathrm{Pd}\left\{\mathrm{C}_{7} \mathrm{H}_{8}(\mathrm{COM}\right. \\
\mathrm{Pd} 1-\mathrm{C} 10 \\
\mathrm{Pd} 1-\mathrm{O} 1 \\
\mathrm{Pd} 2-\mathrm{C} 15 \\
\mathrm{Pd} 2-\mathrm{O} 2\end{array}$ & $\begin{array}{c}\text { d(tmeda) }](\mathrm{O} \\
2.015(6) \\
2.016(5) \\
2.037(6) \\
2.033(5)\end{array}$ & $\begin{array}{l}\mathrm{C} 8-\mathrm{O} 1 \\
\mathrm{C} 13-\mathrm{O} 2\end{array}$ & $\begin{array}{l}1.239(7) \\
1.236(8)\end{array}$ \\
\hline $\begin{array}{l}\mathrm{O} 1-\mathrm{Pd} 1-\mathrm{N} 1 \\
\mathrm{O} 1-\mathrm{Pd} 1-\mathrm{N} 2 \\
\mathrm{O} 2-\mathrm{Pd} 2-\mathrm{N} 3 \\
\mathrm{O} 2-\mathrm{Pd} 2-\mathrm{N} 4 \\
\mathrm{O} 1-\mathrm{C} 8-\mathrm{C} 7 \\
\mathrm{O} 2-\mathrm{C} 13-\mathrm{C} 12\end{array}$ & $\begin{array}{r}92.8(2) \\
176.0(2) \\
93.6(2) \\
173.9(2) \\
119.7(6) \\
119.7(6)\end{array}$ & $\begin{array}{l}\mathrm{O} 1-\mathrm{Pd} 1-\mathrm{C} 10 \\
\mathrm{~N} 1-\mathrm{Pd} 1-\mathrm{N} 2 \\
\mathrm{O} 2-\mathrm{Pd} 2-\mathrm{C} 15 \\
\mathrm{~N} 3-\mathrm{Pd} 2-\mathrm{N} 4 \\
\mathrm{O} 1-\mathrm{C} 8-\mathrm{C} 9 \\
\mathrm{O} 2-\mathrm{C} 13-\mathrm{C} 14\end{array}$ & $\begin{array}{r}84.4(2) \\
84.6(2) \\
84.0(2) \\
84.2(2) \\
119.3(5) \\
119.8(6)\end{array}$ & $\begin{array}{l}\mathrm{N} 1-\mathrm{Pd} 1-\mathrm{C} 10 \\
\mathrm{~N} 2-\mathrm{Pd} 1-\mathrm{C} 10 \\
\mathrm{~N} 3-\mathrm{Pd} 2-\mathrm{C} 15 \\
\mathrm{~N} 4-\mathrm{Pd} 2-\mathrm{C} 15 \\
\mathrm{C} 7-\mathrm{C} 8-\mathrm{C} 9 \\
\mathrm{C} 12-\mathrm{C} 13-\mathrm{C} 14\end{array}$ & $\begin{array}{r}177.3(2) \\
98.2(2) \\
177.3(2) \\
98.3(2) \\
121.0(5) \\
120.5(6)\end{array}$ \\
\hline
\end{tabular}

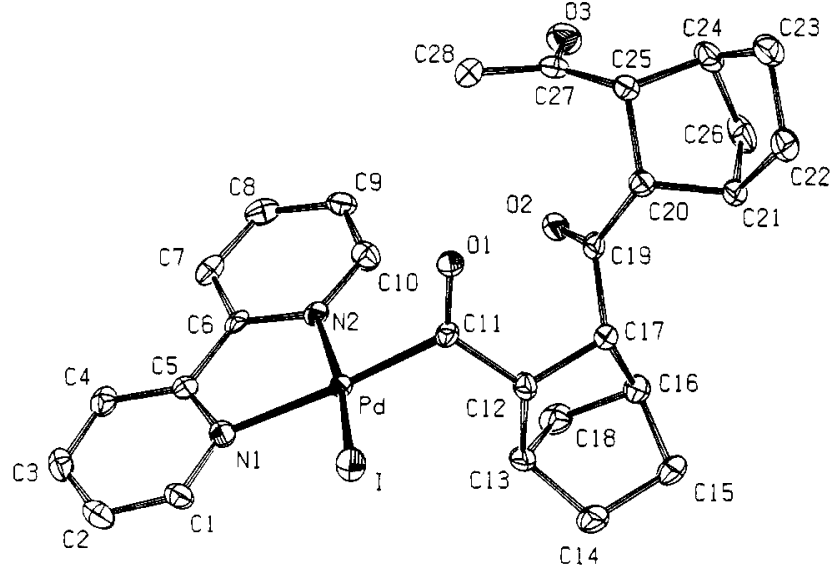

Figure 3. ORTEP plot (50\% probability level) of the molecular structure of $\mathrm{PdI}\left(\mathrm{COC}_{7} \mathrm{H}_{10} \mathrm{COC}_{7} \mathrm{H}_{10} \mathrm{COMe}\right)(\mathrm{bpy})$ (14).

Table 4. Selected ${ }^{13} \mathrm{C}$ NMR and IR Data of the Polyinsertion Products

\begin{tabular}{ccc}
\hline complex & $v(\mathrm{C}-\mathrm{O}), \mathrm{cm}^{-1}$ & \multicolumn{1}{c}{$\delta, \mathrm{ppm}$} \\
\hline $\mathbf{1 2 a}$ & $1672 / 1710$ & $210.92 / 230.63$ \\
$\mathbf{1 2 b}$ & $1663 / 1706$ & $211.37 / 229.73$ \\
$\mathbf{1 3 a}$ & $1582 / 1708$ & $208.00 / 243.39$ \\
$\mathbf{1 3 b}$ & $1587 / 1698$ & $208.17 / 243.53$ \\
$\mathbf{1 3 c}$ & $1601 / 1698$ & $a$ \\
$\mathbf{1 4}$ & $1669 / 1715$ & $210.79 / 213.34 / 232.73$ \\
\hline
\end{tabular}

${ }^{a}$ Not determined due to decomposition.

$\mathrm{C} 11$ on the same side as the $\mathrm{C} 11-\mathrm{O} 1$ keto function. The $\mathrm{Pd}-\mathrm{I}$ $(2.5912(7) \AA$ ) and the $\mathrm{Pd}-\mathrm{C} 11$ (acyl) bond distances (1.952(5) $\AA$ ) have normal values for such bonds trans to a pyridine nitrogen..$^{12,15 a}$ "The structure of the organic substituent of the acyl group shows that there is no interaction of the three carbonyl groups with the metal or with each other. The carbonyl carbon atom (C11) connected to the palladium center shows angles expected for $\mathrm{sp}^{2}$ hybridization, and the $\mathrm{C} 12-\mathrm{C} 11-\mathrm{O} 1$ plane is oriented almost perpendicular to the metal coordination plane $\left(73.6(6)^{\circ}\right)$. Both norbornene moieties are found cis,exo substituted as expected and are syn positioned with respect to each other.

Iodide-Induced Elimination of Norbornene. In an attempt to replace the triflate anion in $\left[\mathrm{Pd}\left(\mathrm{C}_{7} \mathrm{H}_{10} \mathrm{COMe}\right)(\right.$ bpy $\left.)\right] \mathrm{OTf}(\mathbf{8 a})$ by iodide via a methathesis reaction with a large excess $(\approx 20$ equiv) of sodium iodide, we observed immediate elimination ( $<2 \mathrm{~min}$ ) of norbornene instead of anion exchange (eq 3). Both the complex PdI(COMe)(bpy) and free norbornene were readily identified from the ${ }^{1} \mathrm{H}$ NMR spectrum. The formation of norbornene was confirmed by GC-MS. Sodium chloride does not react accordingly. In a similar way, $\left[\mathrm{Pd}\left(\mathrm{C}_{7} \mathrm{H}_{8} \mathrm{COMe}\right)(\mathrm{bpy})\right]-$ OTf $(\mathbf{8 b})$ was reacted with sodium iodide but neither alkene elimination nor anion exchange was observed. When the higher

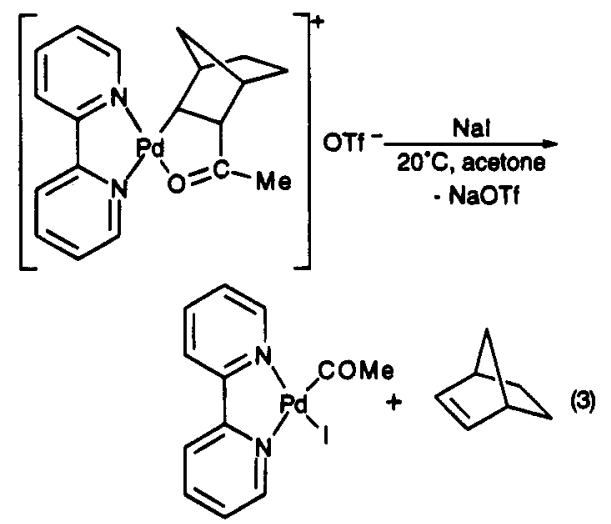

oligomer $\left[\mathrm{Pd}\left(\mathrm{C}_{7} \mathrm{H}_{10} \mathrm{COC}_{7} \mathrm{H}_{10} \mathrm{COMe}\right)(\right.$ bpy $\left.)\right] \mathrm{OTf}(\mathbf{1 3})$ was reacted with 3 equiv of sodium iodide, 1 equiv of norbornene was again formed, but the expected organometallic product $\mathrm{PdI}\left(\mathrm{COC}_{7} \mathrm{H}_{10^{-}}\right.$ $\mathrm{COMe}$ )(bpy) (12b) could not be isolated or even identified from the complex ${ }^{1} \mathrm{H}$ NMR spectrum.

\section{Discussion}

Properties of the Acetyl Complexes. It is well-known that some organopalladium(II) and -(IV) complexes containing nitrogen ligands are more stable than the corresponding complexes with phosphorus ligands. $8 \mathrm{~g}-\mathrm{m}, 11,15,17$ The neutral acetylpalladium(II) complexes $\mathrm{PdX}(\mathrm{COMe})(\mathrm{N}-\mathrm{N})(\mathbf{2 a}-\mathbf{c}, \mathbf{4 a}-$ c) used in this study are good examples as they are stable toward decarbonylation, whereas their cis-phosphorus coordinated analogs are not.

The isomerization observed in the acetyl complexes $\mathbf{4 a - c}$ is not unprecedented. Bäckvall et al. recently found similar isomerizations for bidentate $\mathbf{N}$-donor complexes containing bulky $\pi$-allyl groups. ${ }^{18}$ They showed that these isomerizations

(17) (a) Canty, A. J. Acc. Chem. Res. 1992, 25, 83 and references cited therein. (b) Byers, P. K.; Canty, A. J.; Honeyman, R. T.; Skelton, B. W.; White, A. H. J. Organomet. Chem. 1992, 433, 223. (c) Canty, A. J.; Traill, P. R. J. Organomet. Chem. 1992, 435, C8. (d) Canty, A. J. Platinum Metals Rev. 1993, 37, 2. (e) Bennett, M. A.; Canty, A. J.; Felixberger, J. K.; Rendina, L. M.; Sunderland, C.; Willis, A. C. Inorg. Chem. 1993, 32, 1951 (f) Alsters, P. L.; Engel, P. F.; Hogerheide, M. P.; Copijn, M.; Spek, A. L.; van Koten, G. Organometallics 1993, 12, 1831. (g) Markies, B. A.; Canty, A. J.; Boersma, J.; van Koten, G. Organometallics 1994, 13, 2053.

(18) Gogoll, A.; Örnebro, J.; Grennberg, H.; Bäckvall, J.-E. J. Am. Chem. Soc. 1994, 116, 3631. 
Table 5. Selected Bond Distances $(\AA)$ and Angles $(\mathrm{deg})$ of $\mathrm{PdI}\left(\mathrm{COC}_{7} \mathrm{H}_{10} \mathrm{COC}_{7} \mathrm{H}_{10} \mathrm{COMe}\right)(\mathrm{bpy})(14)$

\begin{tabular}{cccccc}
\hline Pd-N1 & $2.161(4)$ & $\mathrm{Pd}-\mathrm{C} 11$ & $1.952(5)$ & $\mathrm{C} 27-\mathrm{O} 3$ & \\
$\mathrm{Pd}-\mathrm{N} 2$ & $2.098(4)$ & $\mathrm{Pd}-\mathrm{I}$ & $2.5912(7)$ & & \\
$\mathrm{C} 11-\mathrm{O} 1$ & $1.211(7)$ & $\mathrm{C} 19-\mathrm{O} 2$ & $1.209(7)$ & & \\
$\mathrm{I}-\mathrm{Pd}-\mathrm{N} 1$ & $97.67(11)$ & $\mathrm{I}-\mathrm{Pd}-\mathrm{C} 11$ & $86.92(15)$ & $\mathrm{N} 1-\mathrm{Pd}-\mathrm{C} 11$ & $174.95(19)$ \\
$\mathrm{I}-\mathrm{Pd}-\mathrm{N} 2$ & $170.58(14)$ & $\mathrm{N} 1-\mathrm{Pd}-\mathrm{N} 2$ & $77.81(15)$ & $\mathrm{N} 2-\mathrm{Pd}-\mathrm{C} 11$ & $97.35(19)$ \\
$\mathrm{Pd}-\mathrm{C} 11-\mathrm{O} 1$ & $121.3(4)$ & $\mathrm{Pd}-\mathrm{C} 11-\mathrm{C} 12$ & $118.3(4)$ & $\mathrm{O} 1-\mathrm{C} 11-\mathrm{C} 12$ & $120.3(5)$ \\
$\mathrm{O} 2-\mathrm{C} 19-\mathrm{C} 17$ & $121.8(5)$ & $\mathrm{O} 2-\mathrm{C} 19-\mathrm{C} 20$ & $123.1(5)$ & $\mathrm{C} 17-\mathrm{C} 19-\mathrm{C} 20$ & $114.8(4)$ \\
$\mathrm{O} 3-\mathrm{C} 27-\mathrm{C} 25$ & $121.8(5)$ & $\mathrm{O} 3-\mathrm{C} 27-\mathrm{C} 28$ & $121.1(6)$ & $\mathrm{C} 25-\mathrm{C} 27-\mathrm{C} 28$ & $116.7(5)$ \\
\hline
\end{tabular}

Table 6. Details of the Structure Determination and Refinement of 8c, 9, and $\mathbf{1 4}$

\begin{tabular}{|c|c|c|c|}
\hline \multicolumn{4}{|c|}{ Crystal Data } \\
\hline formula & $\mathrm{C}_{22} \mathrm{H}_{23} \mathrm{~N}_{2} \mathrm{OPd} \cdot \mathrm{CF}_{3} \mathrm{O}_{3} \mathrm{~S}(\mathbf{8 c})$ & $\mathrm{C}_{23} \mathrm{H}_{46} \mathrm{~N}_{4} \mathrm{O}_{2} \mathrm{Pd}_{2} \cdot 2 \mathrm{CF}_{3} \mathrm{O}_{3} \mathrm{~S}^{a}(9)$ & $\mathrm{C}_{28} \mathrm{H}_{31} \mathrm{IN}_{2} \mathrm{O}_{3} \mathrm{Pd} \cdot \mathrm{C}_{3} \mathrm{H}_{6} \mathrm{O}(\mathbf{1 4})$ \\
\hline molecular weight & 586.92 & $921.62^{a}$ & 734.97 \\
\hline crystal system & monoclinic & orthorhombic & triclinic \\
\hline space group & $P 2_{1} / n($ no. 14$)$ & $P 22_{1} 2_{1}$ (no. 19) & $P \overline{1}($ no. 2) \\
\hline$a, b, c, \AA$ & $8.3086(4), 15.3894(6), 18.1479(9)$ & $11.176(3), 11.362(1), 30.394(3)$ & $10.128(2), 11.655(2), 13.633(2)$ \\
\hline$\alpha, \beta, \gamma, \operatorname{deg}$ & $90,99.98(1), 90$ & $90,90,90$ & $109.89(1), 100.58(1), 92.92(2)$ \\
\hline$V, \AA^{3}$ & $2285.4(2)$ & $3859(1)$ & $1476.3(4)$ \\
\hline$D_{\text {calc }}, \mathrm{g} \mathrm{cm}^{-3}$ & 1.706 & $1.586^{a}$ & 1.653 \\
\hline$Z$ & 4 & 4 & 2 \\
\hline$F(000)$ & 1184 & $1864^{a}$ & 736 \\
\hline$\mu, \mathrm{cm}^{-1}$ & 9.4 & $11.0^{a}$ & 16.9 \\
\hline crystal size, $\mathrm{mm}$ & $0.12 \times 0.23 \times 0.60$ & $0.4 \times 0.4 \times 0.4$ & $0.4 \times 0.4 \times 0.05$ \\
\hline \multicolumn{4}{|c|}{ Data Collection } \\
\hline temp, $\mathbf{K}$ & 298 & 150 & 150 \\
\hline$\theta_{\min }, \theta_{\max }, \operatorname{deg}$ & $0.1,27.5$ & $0.67,27.5$ & $1.63,27.5$ \\
\hline scan type & $\omega / 2 \theta$ & $\omega$ & $\omega / 2 \theta$ \\
\hline$\Delta \omega, \operatorname{deg}$ & $1.12+0.35 \tan \theta$ & $1.11+0.35 \tan \theta$ & $0.81+0.35 \tan \theta$ \\
\hline hor., ver. aperture, $\mathrm{mm}$ & $3.00,4.00$ & $3.77,4.00$ & $3.00,4.00$ \\
\hline $\mathrm{X}$-ray exposure time, $\mathrm{h}$ & 37 & 45 & 26 \\
\hline linear decay, $\%$ & 10 & 3 & 5 \\
\hline reference reflections & $233 ; 12 \overline{4} ; 162$ & $\overline{2} \overline{2} \overline{5}, 12 \overline{7}, \overline{4} \overline{3} \overline{2}$ & $\overline{2} 24, \overline{2} 2 \overline{4}, \overline{4} 32$ \\
\hline data set $(h k l)$ & $-10: 10 ; 0: 19 ;-23: 23$ & $-14: 14 ; 0: 14 ;-39: 0$ & $-13: 13,-10: 15,-17: 16$ \\
\hline total data & 5715 & 9478 & 8978 \\
\hline total unique data & 4951 & 8854 & 6770 \\
\hline observed data & $3136[I>2.5 \sigma(I)]$ & [no obs. crit. applied] & $5061[I>2.5 \sigma(I)]$ \\
\hline DIFABS corr. range & $0.77,1.21$ & $0.70,1.20$ & $0.78,1.21$ \\
\hline \multicolumn{4}{|c|}{ Refinement } \\
\hline no. of refined parameters & 312 & 435 & 354 \\
\hline final $R^{b}$ & $0.042[I>2.5 \sigma(I)]$ & $0.049\left[8029 F_{0}>4 \sigma\left(F_{0}\right)\right]$ & $0.044[I>2.5 \sigma(I)]$ \\
\hline final $w R 2^{c}$ & & 0.124 & \\
\hline final $R_{\mathrm{w}}{ }^{d}$ & 0.034 & & 0.057 \\
\hline goodness of fit & 1.48 & 1.06 & 2.05 \\
\hline weighting scheme & $1 / \sigma^{2}(F)$ & $1 /\left[\sigma^{2}\left(F_{0}^{2}\right)+\left(0.065^{*} P\right)^{2}+10.78^{*} P\right]^{e}$ & $1 /\left[\sigma^{2}(F)+0.00111\right] F^{2}$ \\
\hline$(\Delta / \sigma)_{\mathrm{av}},(\Delta / \sigma)_{\max }$ & $0.014,0.39$ & $0.000,0.002$ & $0.017,0.090$ \\
\hline min. and max. residual density, $\mathrm{e}^{-3}$ & $-0.42,0.84$ & $-2.12,1.55$ & $-1.32,1.34$ \\
\hline
\end{tabular}

${ }^{a}$ Without disordered solvent contribution (see text). ${ }^{b} R=\Sigma|| F_{\mathrm{o}}|-| F_{\mathrm{c}}|| / \Sigma\left|F_{\mathrm{o}}\right| \cdot{ }^{c} w R 2=\left[\Sigma\left[w\left(F_{\mathrm{o}}{ }^{2}-F_{\mathrm{c}}{ }^{2}\right)^{2}\right] / \Sigma\left[w\left(F_{0}{ }^{2}\right)^{2}\right]\right]^{1 / 2} .{ }^{d} R_{\mathrm{w}}=\left[\Sigma\left[w\left(|| F_{\mathrm{o}} \mid-\right.\right.\right.$ $\left.\left.\left.\left|F_{\mathrm{c}}\right| \mid\right)^{2}\right] / \Sigma\left[w\left(F_{\mathrm{o}}{ }^{2}\right)\right]\right]^{1 / 2} \cdot{ }^{e} P=\left(\max \left(F_{\mathrm{o}}{ }^{2}, 0\right)+2 F_{\mathrm{c}}{ }^{2}\right) / 3$.

occur via $\mathrm{Pd}-\mathrm{N}$ bond breaking followed by isomerization of the resulting three-coordinate intermediate and ligand rotation. The mechanism occurring in our case is yet unknown. However, from Table 1 it can be concluded that the isomerization is faster in acetone, which, together with the negative values of $\Delta S^{\ddagger}$, is consistent with a polar transition state and a nondissociative pathway.

Insertion of Alkenes into Acetylpalladium(II) Complexes. While ionic and neutral phosphorus-coordinated complexes allow insertion of most types of alkenes, $\mathrm{N}$-donor complexes have a strong preference for strained alkenes. Norbornadiene is a special case since it is known to react with both double bonds during $\mathrm{CO} /$ alkene copolymerization, and the second double bond may allow the synthesis of dinuclear complexes. Reaction of norbornadiene with 2 equiv of 5 or 6 (eq 2 ) indeed produced the homoligated dinuclear complexes 9 and $\mathbf{1 0}$, involving most probably $\mathbf{7 b}$ and $\mathbf{8 b}$ as intermediates. Although it could only be shown for the tmeda complex (9), we assume that both 9 and $\mathbf{1 0}$ occur in the trans configuration, i.e., the complexes are $C_{2}$ symmetric (cf. the structure in the solid state, Figure 2). Molecular models suggest that the exclusive forma- tion of this configuration is due to steric interactions between the $\mathrm{N}$-donor ligands during insertion.

Nonstrained alkenes containing a potential donor group, e.g., 2-vinylpyridine, do not insert but most probably only coordinate to the metal leading to unstable adducts resulting in rapid palladium metal deposition upon attempted isolation. Nonstrained alkenes that are activated by electron withdrawing substituents, like methyl methacrylate, insert but do not give stable complexes either. Strained norbornene-type alkenes do give stable insertion products, probably by excluding the possibility of $\beta$-elimination. The stability of the insertion products will be further enhanced by intramolecular coordination of the carbonyl group. This coordination is particularly efficient for strained alkenes as their rigid geometry forces the acyl group in the direction of the metal. In the case of styrene, only coordination of the acyl group prevents $\beta$-hydrogen elimination. Nevertheless, we found evidence for the formation of the insertion product, accompanied by several unidentified side products. This contrasts with the report by Brookhart et al. on the clean insertion of 4-tert-butylstyrene. ${ }^{8 j}$ It may be that either the low temperature $\left(c a .-80^{\circ} \mathrm{C}\right)$ used by Brookhart et al. in 
Table 7. Final Coordinates $(\AA)$ and Equivalent Isotropic Thermal Parameters $\left(\AA^{2}\right)$ of the Non-Hydrogen Atoms for $8 c$

\begin{tabular}{lllll}
\hline atom & \multicolumn{1}{c}{$x$} & \multicolumn{1}{c}{$y$} & \multicolumn{1}{c}{$z$} & \multicolumn{1}{c}{$U_{\text {eq }}{ }^{a}$} \\
\hline $\mathrm{Pd}$ & $0.65102(5)$ & $0.38322(2)$ & $0.50879(2)$ & $0.0452(1)$ \\
$\mathrm{O}(1)$ & $0.6496(4)$ & $0.2931(2)$ & $0.59005(16)$ & $0.0604(12)$ \\
$\mathrm{N}(1)$ & $0.6521(5)$ & $0.4793(2)$ & $0.4337(2)$ & $0.0475(14)$ \\
$\mathrm{N}(2)$ & $0.8037(5)$ & $0.4751(3)$ & $0.5743(2)$ & $0.0534(17)$ \\
$\mathrm{C}(1)$ & $0.5665(6)$ & $0.4807(3)$ & $0.3638(3)$ & $0.0557(19)$ \\
$\mathrm{C}(2)$ & $0.5720(7)$ & $0.5484(4)$ & $0.3162(3)$ & $0.073(3)$ \\
$\mathrm{C}(3)$ & $0.6693(8)$ & $0.6194(4)$ & $0.3395(3)$ & $0.078(2)$ \\
$\mathrm{C}(4)$ & $0.7575(7)$ & $0.6188(4)$ & $0.4116(3)$ & $0.070(2)$ \\
$\mathrm{C}(5)$ & $0.7464(6)$ & $0.5499(3)$ & $0.4573(3)$ & $0.0515(17)$ \\
$\mathrm{C}(6)$ & $0.8313(6)$ & $0.5457(3)$ & $0.5359(3)$ & $0.0533(17)$ \\
$\mathrm{C}(7)$ & $0.9354(6)$ & $0.6105(4)$ & $0.5693(3)$ & $0.070(2)$ \\
$\mathrm{C}(8)$ & $1.0072(7)$ & $0.6012(4)$ & $0.6430(4)$ & $0.079(3)$ \\
$\mathrm{C}(9)$ & $0.9770(7)$ & $0.5294(4)$ & $0.6805(3)$ & $0.081(3)$ \\
$\mathrm{C}(10)$ & $0.8752(7)$ & $0.4678(4)$ & $0.6455(3)$ & $0.072(2)$ \\
$\mathrm{C}(11)$ & $0.5146(5)$ & $0.2943(3)$ & $0.4436(2)$ & $0.0424(17)$ \\
$\mathrm{C}(12)$ & $0.6005(6)$ & $\mathbf{0 . 2 5 8 9 ( 3 )}$ & $0.3811(3)$ & $0.0509(17)$ \\
$\mathrm{C}(13)$ & $0.4823(7)$ & $0.1979(3)$ & $0.3287(3)$ & $0.0588(19)$ \\
$\mathrm{C}(14)$ & $0.3077(7)$ & $\mathbf{0 . 2 2 6 6 ( 4 )}$ & $0.3050(3)$ & $0.078(2)$ \\
$\mathrm{C}(15)$ & $0.2080(8)$ & $0.1694(4)$ & $0.3394(3)$ & $0.080(3)$ \\
$\mathrm{C}(16)$ & $0.2971(9)$ & $0.1019(5)$ & $0.3779(3)$ & $0.097(3)$ \\
$\mathrm{C}(17)$ & $0.4735(7)$ & $0.1160(3)$ & $0.3775(3)$ & $0.070(2)$ \\
$\mathrm{C}(18)$ & $0.5848(7)$ & $0.1408(3)$ & $0.4520(3)$ & $0.0613(19)$ \\
$\mathrm{C}(19)$ & $0.4983(6)$ & $0.2124(3)$ & $0.4917(2)$ & $0.0494(17)$ \\
$\mathrm{C}(20)$ & $0.7176(6)$ & $0.1921(3)$ & $0.4239(3)$ & $0.060(2)$ \\
$\mathrm{C}(21)$ & $0.5776(6)$ & $0.2235(3)$ & $0.5702(3)$ & $0.0546(19)$ \\
$\mathrm{C}(22)$ & $0.5718(7)$ & $0.1546(4)$ & $0.6272(3)$ & $0.074(2)$ \\
$\mathrm{S}$ & $0.5723(2)$ & $0.34398(10)$ & $0.16786(8)$ & $0.0684(6)$ \\
$\mathrm{F}(1)$ & $0.4417(5)$ & $0.4407(3)$ & $0.0580(2)$ & $0.1184(19)$ \\
$\mathrm{F}(2)$ & $0.6442(7)$ & $0.4977(3)$ & $0.1312(3)$ & $0.188(3)$ \\
$\mathrm{F}(3)$ & $0.6839(5)$ & $0.4031(4)$ & $0.0533(2)$ & $0.173(3)$ \\
$\mathrm{O}(2)$ & $0.5077(6)$ & $0.2716(3)$ & $0.1221(3)$ & $0.120(2)$ \\
$\mathrm{O}(3)$ & $0.7341(5)$ & $0.3324(3)$ & $0.2058(2)$ & $0.0997(19)$ \\
$\mathrm{O}(4)$ & $0.4596(5)$ & $0.3826(3)$ & $0.20974(19)$ & $0.0814(16)$ \\
$\mathrm{C}(23)$ & $0.5900(9)$ & $0.4240(5)$ & $0.0995(4)$ & $0.094(3)$ \\
\hline & & &
\end{tabular}

${ }^{a} U_{\text {eq }}=1 / 3$ of the trace of the orthogonalized $U$.

the alkene insertion reaction slows down the decomposition and or that the formation of a $\eta^{3}$-benzallyl species provides additional stabilization of the insertion product. In view of our results it seems less likely that the borate anion $\left[\mathrm{B}\left(\mathrm{C}_{6} \mathrm{H}_{3}\left\{\mathrm{CF}_{3}\right\}_{2-}\right.\right.$ $\left.3,5)_{4}\right]^{-}$is involved.

The higher reactivity of the ionic complexes (5 and 6) compared to the neutral complexes (2a,c and 4a,c; Scheme 3) will certainly be related to the better availability of a coordination site. However, Sen et al. found that an associative mechanism in which the alkene coordinates in an apical position prior to insertion cannot be fully ruled out even for monodentate phosphine containing complexes. ${ }^{4 \mathrm{~d}, 7 \mathrm{~d}}$ Our results show that it is not only the nature of the donor atoms of the ligand, i.e., $\mathrm{N}$ or $\mathrm{P}$, that influence the insertion reaction but that also the type of donating groups (amine or imine) together with the anion, alkene, and solvent are of importance. For instance, only norbornadiene reacts with all four neutral acetyl complexes, irrespective of the solvent and halide, whereas norbornene only reacts with the neutral bpy complexes $(\mathbf{4 a}, \mathbf{c})$ in $\mathrm{CDCl}_{3}$. The nature of the solvent is important since it will compete with the alkene for a coordination site on the metal. This may explain why norbornene does not insert in $\mathrm{CD}_{3} \mathrm{COCD}_{3}$ while it does so in the more weakly coordinating $\mathrm{CDCl}_{3}$.

Finally, the ligand and the anion are important. Based on the order of trans-labilizing influence, i.e., bpy, tmeda $<\mathrm{Cl}<$ $\mathrm{Br}<\mathrm{I}<\mathrm{COMe},{ }^{19}$ it is the $\mathrm{N}$-donor of the ligand trans to the acetyl group that is expected to dissociate. This would result in an unproductive intermediate because the incoming alkene and the acetyl group are trans positioned. The other possibility is that dissociation of the $\mathrm{N}$-donor trans to the halide occurs which would result in a cis-configuration that allows migratory insertion leading to the insertion product. However, this pathway involves an unfavorable Jahn-Teller isomerization of
Table 8. Final Coordinates $(\AA)$ and Equivalent Isotropic Thermal Parameters $\left(\AA^{2}\right)$ of the Non-Hydrogen Atoms for 9

\begin{tabular}{|c|c|c|c|c|}
\hline atom & $x$ & $y$ & $z$ & $U_{\mathrm{eq}}{ }^{a}$ \\
\hline $\operatorname{Pd}(1)$ & $0.80013(3)$ & $-0.07745(4)$ & $0.00035(1)$ & $0.0234(1)$ \\
\hline $\operatorname{Pd}(2)$ & $0.89516(4)$ & $0.12867(4)$ & $0.20333(1)$ & $0.0271(1)$ \\
\hline$O(1)$ & $0.9085(4)$ & $0.0633(4)$ & $-0.00638(13)$ & $0.0340(12)$ \\
\hline$O(2)$ & $0.7392(4)$ & $0.0368(4)$ & $0.2057(2)$ & $0.0390(14)$ \\
\hline $\mathrm{N}(1)$ & $0.7462(5)$ & $-0.0726(5)$ & $-0.0682(2)$ & $0.0360(16)$ \\
\hline $\mathrm{N}(2)$ & $0.6940(4)$ & $-0.2279(4)$ & $0.0034(2)$ & $0.0243(12)$ \\
\hline $\mathrm{N}(3)$ & $0.8540(5)$ & $0.2303(5)$ & $0.2617(2)$ & $0.0353(16)$ \\
\hline $\mathrm{N}(4)$ & $1.0578(4)$ & $0.2122(5)$ & $0.2069(2)$ & $0.0300(14)$ \\
\hline$C(1)$ & $0.8525(7)$ & $-0.0634(9)$ & $-0.0987(2)$ & $0.054(3)$ \\
\hline$C(2)$ & $0.6651(8)$ & $0.0295(7)$ & $-0.0730(3)$ & $0.054(3)$ \\
\hline $\mathrm{C}(3)$ & $0.6814(6)$ & $-0.1843(6)$ & $-0.0766(2)$ & $0.0350(19)$ \\
\hline $\mathrm{C}(4)$ & $0.6158(6)$ & $-0.2165(6)$ & $-0.0360(2)$ & $0.0347(17)$ \\
\hline $\mathrm{C}(5)$ & $0.7750(5)$ & $-0.3320(5)$ & $-0.0017(3)$ & $0.0350(17)$ \\
\hline$C(6)$ & $0.6195(6)$ & $-0.2439(6)$ & $0.0426(2)$ & $0.0360(19)$ \\
\hline$C(7)$ & $1.0609(7)$ & $0.1861(7)$ & $0.0226(2)$ & $0.048(3)$ \\
\hline$C(8)$ & $0.9719(5)$ & $0.0878(6)$ & $0.0258(2)$ & $0.0313(17)$ \\
\hline $\mathrm{C}(9)$ & $0.9567(5)$ & $0.0201(5)$ & $0.0674(2)$ & $0.0263(17)$ \\
\hline$C(10)$ & $0.8551(5)$ & $-0.0751(5)$ & $0.0635(2)$ & $0.0240(14)$ \\
\hline $\mathrm{C}(11)$ & $0.7652(5)$ & $-0.0331(5)$ & $0.0981(2)$ & $0.0250(16)$ \\
\hline$C(12)$ & $0.8207(5)$ & $-0.0602(5)$ & $0.1442(2)$ & $57(17)$ \\
\hline$C(13)$ & $0.7304(6)$ & $-0.0459(6)$ & $0.1795(2)$ & $0.0320(17)$ \\
\hline$C(14)$ & $0.6278(7)$ & $-0.1295(7)$ & $0.1832(2)$ & $0.045(2)$ \\
\hline$C(15)$ & $0.9254(5)$ & $0.0324(5)$ & $0.1479(2)$ & $0.0260(17)$ \\
\hline$C(16)$ & $0.9101(5)$ & $0.1014(5)$ & $0.1050(2)$ & $0.0267(17)$ \\
\hline$C(17)$ & $0.7762(5)$ & $0.1019(5)$ & $0.0967(2)$ & $0.0263(16)$ \\
\hline$C(18)$ & $0.8032(9)$ & $0.1585(7)$ & $0.2970(2)$ & $0.051(2)$ \\
\hline$C(19)$ & $0.7631(7)$ & $0.3214(7)$ & $0.2486(2)$ & $0.044(2)$ \\
\hline$C(20)$ & $0.9668(7)$ & $0.2839(6)$ & $0.2755(2)$ & $0.0387(19)$ \\
\hline$C(21)$ & $1.0407(7)$ & $0.3168(6)$ & $0.2353(2)$ & $0.0393(19)$ \\
\hline$C(22)$ & $1.1462(6)$ & $0.1310(7)$ & $0.2264(2)$ & $0.042(2)$ \\
\hline$C(23)$ & $1.1095(7)$ & $0.2561(6)$ & $0.1653(2)$ & $0.0397(19)$ \\
\hline$S(1)$ & $0.8477(2)$ & $0.5643(2)$ & $0.13599(6)$ & $0.0426(5)$ \\
\hline $\mathrm{F}(1)$ & 0.68 & 0.48 & 0.0 & 30(19) \\
\hline $\mathrm{F}(2)$ & $0.8548(7)$ & $0.3955(6)$ & $0.0789(2)$ & $0.102(3)$ \\
\hline$F(3)$ & $0.7314(6)$ & $0.3664(5)$ & $0.1351(2)$ & $0.083(2)$ \\
\hline $\mathrm{O}(3)$ & $0.7520(7)$ & $0.6105(7)$ & $0.1623(3)$ & $0.084(3)$ \\
\hline $\mathrm{O}(4)$ & $0.8869(6)$ & $0.6410(5)$ & $0.1031(2)$ & $0.0613(19)$ \\
\hline$O(5)$ & $0.9389(6)$ & $0.5102(6)$ & $0.1614(2)$ & $0.059(2)$ \\
\hline$C(24)$ & $0.7758(10)$ & $0.4463(7)$ & $0.1080(3)$ & $0.060(3)$ \\
\hline$S(2)$ & $0.3482(2)$ & $-0.0065(2)$ & $0.11446(7)$ & $0.0470(6)$ \\
\hline$F(4)$ & $0.3345(6)$ & $0.2076(6)$ & $0.0865(3)$ & $0.095(3)$ \\
\hline$F(5)$ & $0.5106(5)$ & $0.1315(7)$ & $0.0808(3)$ & $0.112(3)$ \\
\hline$F(6)$ & $0.3769(7)$ & $0.0812(7)$ & $0.0359(2)$ & $0.098(3)$ \\
\hline $\mathrm{O}(6)$ & $0.4166(5)$ & $-0.1063(5)$ & $0.1007(2)$ & $0.0507(19)$ \\
\hline$O(7)$ & $0.3769(7)$ & $0.0353(7)$ & $0.1567(2)$ & $0.086(3)$ \\
\hline$O(8)$ & $0.2219(4)$ & $-0.0162(7)$ & $0.1052(3)$ & $0.074(3)$ \\
\hline$C(25)$ & $0.3949(9)$ & $0.1097(10)$ & $0.0775(4)$ & $0.072(4)$ \\
\hline
\end{tabular}

${ }^{a} U_{\text {eq }}=1 / 3$ of the trace of the orthogonalized $U$.

the three-coordinate intermediate. A third possibility involves (partial) $\mathrm{Pd}-\mathrm{X}$ bond breaking (helped by solvation) to allow alkene coordination cis to the acetyl group. The important role played by the anion is suggested by the fast iodide-induced elimination of norbornene from $\left[\mathrm{Pd}\left(\mathrm{C}_{7} \mathrm{H}_{10} \mathrm{COMe}\right)(\mathrm{bpy})\right] \mathrm{OTf}$ (8a) in acetone, and the unreactivity of the norbornadiene insertion product $\left[\mathrm{Pd}\left(\mathrm{C}_{7} \mathrm{H}_{8} \mathrm{COMe}\right)(\mathrm{bpy})\right]$ OTf $(\mathbf{8 b})$ in the same reaction. These results, together with the formation of $\mathbf{8 a}$ from the deinsertion of 5-norbornene-endo-2,3-dicarboxylic anhydride during recrystallization of $13 \mathrm{c}$, strongly suggest that alkene insertion is an equilibrium which can be shifted under the correct conditions.

The molecular structures (Figures 1 and 2) of the ionic alkene insertion products $\left[\mathrm{Pd}\left(\mathrm{C}_{10} \mathrm{H}_{12} \mathrm{COMe}\right)(\right.$ bpy) $] \mathrm{OTf}(8 \mathrm{c})$ and $[($ tmeda)$\left.\mathrm{Pd}\left\{\mathrm{C}_{7} \mathrm{H}_{8}(\mathrm{COMe})_{2}-2,5\right\} \mathrm{Pd}(\mathrm{tmeda})\right](\mathrm{OTf})_{2}(9)$ show several features. Firstly, as is normal observed in palladium chemistry, exclusive cis-exo addition to the alkene functionality is observed, as the exo face is more accessible than the endo face. Secondly, the insertion is regioselective as only the norbornenetype double bond of $\mathbf{8 c}$ has reacted. A third feature is the strong coordination between the metal and the carbonyl oxygen. The $\mathrm{Pd}-\mathrm{O}$ bond distances $(2.016(5)-2.026(3) \AA$ (Table 3) are 
Table 9. Final Coordinates $(\AA)$ and Equivalent Isotropic Thermal Parameters $\left(\AA^{2}\right)$ of the Non-Hydrogen Atoms for 14

\begin{tabular}{|c|c|c|c|c|}
\hline atom & $x$ & $y$ & $z$ & $U_{\mathrm{eq}}{ }^{a}$ \\
\hline 1 & $0.39269(3)$ & $0.80551(3)$ & $-0.02491(3)$ & $0.0256(1)$ \\
\hline $\mathrm{Pd}$ & $0.17269(4)$ & $.79948(3)$ & $0.04570(3)$ & $.0148(1)$ \\
\hline $\mathrm{O}(1)$ & $0.3186(4)$ & $0.8727(3)$ & $0.2552(3)$ & $0.0220(11)$ \\
\hline$O(2)$ & $0.1735(4)$ & $0.7239(4)$ & $0.3529(3)$ & $0.0238(11)$ \\
\hline$O(3)$ & $0.1150(4)$ & $0.8881(4)$ & $0.5634(3)$ & $0.0322(14)$ \\
\hline $\mathrm{N}(1)$ & $0.0357(4)$ & $0.8221(4)$ & $-0.0862(3)$ & $0.0191(12)$ \\
\hline $\mathrm{N}(2)$ & $-0.0069(4)$ & $0.8239(4)$ & $0.1022(3)$ & $0.0167(12)$ \\
\hline $\mathrm{C}(1)$ & $0.0612(6)$ & $0.8169(5)$ & $-0.1806(4)$ & $0.0220(17)$ \\
\hline$C(2)$ & $-0.0262(6)$ & $0.8497(5)$ & $-0.2541(4)$ & $0.0263(17)$ \\
\hline$C(3)$ & $-0.1444(6)$ & $0.8923(5)$ & $-0.2274(4)$ & $0.0235(17)$ \\
\hline$C(4)$ & $-0.1745(5)$ & $0.8969(5)$ & $-0.1323(4)$ & $0.0214(16)$ \\
\hline$C(5)$ & $-0.0836(5)$ & $0.8597(4)$ & $-0.0631(4)$ & $0.0173(12)$ \\
\hline$C(6)$ & $-0.1072(5)$ & 0.8600 & $0.0403(4)$ & (14) \\
\hline$C(7)$ & $-0.2255(5)$ & 0.892 & 0.0 & 0.0 \\
\hline $\mathrm{C}(8)$ & $-0.2435(5)$ & $0.8864(5)$ & $0.1719(5)$ & $0.0246(16)$ \\
\hline$C(9)$ & $-0.1420(6)$ & $0.8500(5)$ & $0.2336(4)$ & $0.0225(17)$ \\
\hline$C(10)$ & $-0.0251(5)$ & $0.8200(5)$ & $0.1958(4)$ & $0.0216(17)$ \\
\hline $\mathrm{C}(11)$ & $0.2852(5)$ & $0.7852(5)$ & $0.1726(4)$ & $0.0172(16)$ \\
\hline$C(12)$ & $0.3343(5)$ & $13(5)$ & $545(4)$ & $8(16)$ \\
\hline$C(13)$ & 0.2 & 5) & & (17) \\
\hline$C(14)$ & 0.3 & 5) & 0.0 & (19) \\
\hline$C(15)$ & $0.3528(6)$ & $0.4096(5)$ & $0.1600(5)$ & $0.0264(17)$ \\
\hline$C(16)$ & $0.2673(6)$ & $0.4984(5)$ & $0.2252(4)$ & $0.0241(17)$ \\
\hline$C(17)$ & $0.3489(5)$ & $0.6281(5)$ & $0.2687(4)$ & $0.0191(16)$ \\
\hline $\mathrm{C}(18)$ & 0.15 & 0.5 & (5) & $6(17)$ \\
\hline$C(19)$ & & $0.7144(5)$ & & $0.0202(17)$ \\
\hline$C(20)$ & & & & $199(17)$ \\
\hline$C(21)$ & 0.4 & 0.672 & 0.5 & $7(17)$ \\
\hline$C(22)$ & $0.5590(6)$ & $0.7238(6)$ & $0.6020(5)$ & $0.0292(17)$ \\
\hline$C(23)$ & $0.5045(6)$ & $0.8185(6)$ & $0.6941(5)$ & $0.0292(17)$ \\
\hline$C(24)$ & $0.3548(6)$ & 0.81 & $0.6433(5)$ & $0.0266(17)$ \\
\hline$C(25)$ & $0.3486(5)$ & $0.8717(5)$ & $0.5583(4)$ & $0.0207(17)$ \\
\hline$C(26)$ & (6) & $53(6)$ & $64(5)$ & $0(17)$ \\
\hline $\mathrm{C}(27)$ & & & & $42(17)$ \\
\hline$C(28)$ & $0.2070(6)$ & $1.0044(6)$ & $0.4732(5)$ & $0.0304(17)$ \\
\hline $\mathrm{O}(4)$ & $0.3062(5)$ & $0.3253(5)$ & $0.6353(5)$ & $0.062(2)$ \\
\hline $\mathrm{C}(29)$ & $0.1031(9)$ & $03867(9)$ & $0.5641(8)$ & $0.078(4)$ \\
\hline$C(30)$ & $0.2151(7)$ & $0.3866(6)$ & $0.6523(6)$ & $0.039(2)$ \\
\hline$C(31)$ & $0.2111(11)$ & $0.4619(8)$ & $0.7646(7)$ & $0.077(4)$ \\
\hline
\end{tabular}

${ }^{a} U_{\mathrm{eq}}=1 / 3$ of the trace of the orthogonalized $U$.

significantly shorter than those in the phosphine coordinated complex $\left[\mathrm{Pd}\left(\mathrm{C}_{7} \mathrm{H}_{10} \mathrm{COMe}\right)\left(\mathrm{PPh}_{3}\right)_{2}\right] \mathrm{BF}_{4}(2.114(6) \AA),{ }^{7 \mathrm{~d}}$ reflecting again the small trans influence of a nitrogen donor compared to phosphorus. Also the $(\mathrm{C}-\mathrm{O})$ stretching frequencies and ${ }^{13} \mathrm{C}$ NMR shifts (cf. Table 2) are in accord with strong $\mathrm{Pd}-\mathrm{O}$ coordination.

Co-oligomerization of $\mathrm{CO}$ and Norbornene (Derivatives) on a Metal Center. In the reports published so far, the intermediates during CO/alkene copolymerization are either not isolated or the range of alkenes is limited to norbornadiene. The general route presented here allows the range of alkenes to be extended to other (less) strained alkenes and enables the complete characterization of all intermediates in the step-bystep co-oligomerization. It is now well-understood why a noncoordinating anion is needed in order to produce a good catalyst for the $\mathrm{CO} /$ alkene copolymerization. Firstly, ionic acylpalladium(II) complexes are more reactive toward alkenes than their neutral counterparts. Secondly, in order to obtain stable alkene insertion products it is essential that a noncoordinating anion is present $\left(e . g ., \mathrm{OTf}^{-}\right)$as this allows coordination of the carbonyl group to prevent $\beta$-hydrogen elimination. The other propagation step, i.e., the insertion of $\mathrm{CO}$, has also been shown to be much faster for ionic alkyl complexes than for neutral ones. ${ }^{8 c}$ However, when isolation of the (intermediate) acyl complexes is desired, the presence of a well-coordinating anion (i.e., a halide) to block the decarbonylation pathway is required. This is supported by an earlier study on the carbonylation of allylpalladium(II) complexes reported by Yamamoto et al. ${ }^{20}$ They found that when complexes of the type $\left[\operatorname{Pd}\left(\eta^{3}\right.\right.$ allyl) $\left.\left(\mathrm{PMe}_{3}\right)\right] \mathrm{X}(\mathrm{X}=$ halide $)$ were treated with $\mathrm{CO}(1 \mathrm{~atm})$, the carbonylation products $\mathrm{PdX}(\mathrm{CO}$-allyl $)\left(\mathrm{PMe}_{3}\right)$ could be isolated within a few hours, whereas the corresponding $\mathrm{BF}_{4}{ }^{-}$complexes did not undergo $\mathrm{CO}$ insertion within 1 day even at $20 \mathrm{~atm}$. Moreover, treatment of the halide complexes with $\mathrm{AgBF}_{4}$ resulted in rapid decarbonylation. They attributed these results to the blocking effect of the halide on the availability of a coordination site.

The second alkene insertion to give $13 a-c$ can be carried out in the absence of a $\mathrm{CO}$ atmosphere without apparent decarbonylation of the ionic acyl intermediate $\left[\mathrm{Pd}\left(\mathrm{COC}_{7} \mathrm{H}_{10^{-}}\right.\right.$ $\mathrm{COMe})(\mathrm{MeCN})(\mathrm{bpy})] \mathrm{OTf}$ on the time scale of the reaction. Nevertheless, attempts to isolate the ionic acyl complex invariably failed and gave the decarbonylation product $\mathbf{8 a}$ instead. This is also observed for the synthesis of $\mathbf{8 a}-\mathbf{e}$, and thus it can be concluded that decarbonylation must be slower than alkene insertion. This is consistent with the reports on CO/alkene copolymerization. ${ }^{4,5}$

As described above, we carried out one more $\mathrm{CO}$ insertion into the $\mathrm{Pd}-\mathrm{C}$ bond of $13 \mathrm{a}$ in the presence of sodium iodide to give $\mathrm{PdI}\left(\mathrm{COC}_{7} \mathrm{H}_{10} \mathrm{COC}_{7} \mathrm{H}_{10} \mathrm{COMe}\right)($ bpy) (14). This neutral complex, which is the result of the stepwise anion-controlled sequential insertion reactions of norbornene, $\mathrm{CO}$, norbornene, and $\mathrm{CO}$ starting from the acetyl complexes $4 \mathrm{a}-\mathrm{c}$, is no less than a metal-bound co-oligomer of $\mathrm{CO}$ and norbornene. Although we did not pursue further extension of the chain, we expect this can be done at will. Of course, the complex will gradually develop a more organic character, and workup will become more difficult due to its enhanced solubility in hydrocarbons. The molecular structure of 14 (Figure 3 ) shows a syn positioning of the two norbornene moieties. This indicates that the orientation of the second norbornene before and during insertion is governed by the first inserted norbornene. This is consistent with reports on the stereospecific character of the copolymerization of $\mathrm{CO}$ with norbornene and other alkenes. ${ }^{4,5}$

Norbornadiene is a special case in these co-oligomerization reactions. As reported by Van Asselt et al., it is the only alkene that allows the synthesis of metal-bound co-oligomers, starting from $\mathrm{PdCl}(\mathrm{COMe})(\mathrm{BIAN})(16)$, without the need to vary the anion with each successive step. ${ }^{13}$ They attributed this to the rigidity of the BIAN ligand which, in their opinion, activates these complexes for this type of reactions. As we observed that the complexes $\mathbf{4 a , c}$, which contain the less rigid bpy ligand, show the same behavior, it is likely that the nature of the ligand is not the main factor determining the insertion of norbornadiene into the palladium-acyl bond in neutral complexes.

\section{Concluding Remarks}

We have shown that the stability of the various products obtained after either alkene or $\mathrm{CO}$ insertion is controlled by the type of anion present in the complex. Strongly coordinating anions (e.g, halides) stabilize the acyl complexes but destabilize the alkene insertion products, whereas noncoordinating anions (e.g., trifluoromethanesulfonate) have the reverse effect. As a consequence of this, the alkene insertion step is reversible, and the equilibrium involved is controlled by the anion, the nature of the alkene and the solvent. By optimizing the reaction conditions, we are able to perform the copolymerization of strained alkenes, like norbornene and its derivatives, with carbon monoxide on a palladium(II) center with complete control of the intermediate steps. In principle, this route allows the synthesis of highly regioselectively functionalized copolymers. Moreover, since the stereoselectivity of the chain-growth is most probably controlled by the first alkene insertion, it is only necessary to control the stereochemistry of the first alkene 
insertion step in order to prepare stereoregular copolymers. The dinuclear palladium-acyl complexes ( 9 and 10 ) are, in principle, potential bidirectional catalysts, which may allow the synthesis of copolymers with a much higher mean molecular weight. The work presented here complements the earlier reported studies and provides additional insight into factors that may also be important in catalytic $\mathrm{CO} /$ alkene copolymerization.

\section{Experimental Section}

General Procedures. All operations were conducted in an atmosphere of dry nitrogen using established Schlenk-type techniques. Pentane and diethyl ether were freshly distilled from sodium benzophenone ketyl; methylene chloride was distilled from calcium hydride. All other solvents were used as received. The solvents acetonitrile (p.a.) and acetone (p.a.), and the compounds 2,2'-bipyridyl, norbomene, norbornadiene, dicyclopentadiene, methyl methacrylate, styrene (p.a.), $\alpha$-methylstyrene, cyclopentene, cyclohexene, cycloheptene, 2-vinylpyridine, methyl vinyl ketone, 2,3-dihydrofuran, maleic anhydride, sodium chloride (p.a.), and anhydrous sodium iodide $(99+\%)$ were obtained from Janssen Chimica. Carbon monoxide and ethylene was obtained from AGA gas BV. Silver trifluoromethanesulfonate (AgOTf) and dibenzylideneacetone were obtained from Aldrich. $\mathrm{PdXMe}(\mathrm{tmeda}){ }^{21}$ $\mathrm{PdX}(\mathrm{COMe})(\mathrm{tmeda}),{ }^{8 \mathrm{~g}}$ 5-norbornene-endo-2,3-dicarboxylic anhydride, ${ }^{22 \mathrm{a}}$ and 7-oxa-5-norbornene-exo-2,3-dicarboxylic anhydride ${ }^{22 b}$ were prepared following literature procedures. $\mathrm{CDCl}_{3}, \mathrm{CD}_{3} \mathrm{OD}$, and $\mathrm{CD}_{3} \mathrm{COCD}_{3}$ were obtained from ISOTEC Inc. ${ }^{1} \mathrm{H}(200$ or $300 \mathrm{MHz})$ and ${ }^{13} \mathrm{C}(50$ or $75 \mathrm{MHz}$ ) NMR spectra were recorded on Bruker AC200 or AC300 spectrometers at ambient temperature unless otherwise noted. Chemical shifts $(\delta)$ are given in ppm relative to tetramethylsilane. Elemental analyses were performed by the Institute for Applied Chemistry (TNO), Zeist, The Netherlands and by Dornis u. Kolbe, Mülheim a. d. Ruhr, Federal Republic of Germany.

Synthesis of PdXMe(2,2'-bipyridyl) (3a-c) and PdX(COMe)(2,2'bipyridyl) $(4 a-c)$ via Ligand Exchange. The following synthesis of $4 \mathrm{c}$ is a typical procedure: To a solution of $0.16 \mathrm{~g}(0.41 \mathrm{mmol})$ of PdI(COMe)(tmeda) (2c) in $50 \mathrm{~mL}$ of methylene chloride was added, at 0 ${ }^{\circ} \mathrm{C}, 0.20 \mathrm{~g}(1.28 \mathrm{mmol})$ of $2,2^{\prime}$-bipyridyl. After stirring the solution for $16 \mathrm{~h}$ the volatiles were evaporated in vacuo, and the residue washed with diethyl ether $(3 \times 50 \mathrm{~mL})$ and dried in vacuo: yield $0.15 \mathrm{~g}(85 \%)$. The complexes $3 \mathrm{a}-\mathrm{c}$ were obtained in similar yields, and the NMR spectra are identical to those reported by Canty and Byers. ${ }^{12}$

PdCl(COMe)(bpy) (4a): yield $89 \% ; \mathrm{mp} 163{ }^{\circ} \mathrm{C} \mathrm{dec;}{ }^{1} \mathrm{H}$ NMR (200 $\mathrm{MHz}, \mathrm{CDCl}_{3}$, d) 2.64 (s, 3, $\mathrm{COCH}_{3}$ ), 7.45 (m, 2, bpy), 7.9-8.2 (m, 4, bpy), 8.37 (d, $J=7.6 \mathrm{~Hz}, 1$, bpy), $8.88\left(\mathrm{~d}, J=7.7 \mathrm{~Hz}, 1\right.$ bpy); ${ }^{13} \mathrm{C}$ NMR $\left(50 \mathrm{MHz}, \mathrm{CDCl}_{3}, \delta\right) 36.63\left(\mathrm{COCH}_{3}\right), 121.93,122.90,125.98$, $126.62,139.31,139.45,148.95,150.70,152.10,154.49$ (bpy), 231.54 (CO); IR spectrum $\left(\mathrm{KBr}, \mathrm{cm}^{-1}\right) 1664(\mathrm{CO})$. Anal. Calcd for $\mathrm{C}_{12} \mathrm{H}_{11-}$ $\mathrm{N}_{2}$ ClOPd: C $42.25 ; \mathrm{H}, 3.25 ; \mathrm{N}, 8.21$. Found: C, $42.20 ; \mathrm{H}, 3.31 ; \mathrm{N}$, 8.29 .

$\operatorname{PdBr}(\mathrm{COMe})(\mathrm{bpy})(\mathbf{4 b}):$ yield $74 \% ; \mathrm{mp}>200{ }^{\circ} \mathrm{C} \mathrm{dec} ;{ }^{1} \mathrm{H}$ NMR $\left(200 \mathrm{MHz}, \mathrm{CDCl}_{3}, \delta\right) 2.67$ (s, 3, $\mathrm{COCH}_{3}$ ), 7.43 (m, 2, bpy), 7.9-8.4 (m, 5, bpy), 8.94 (d, $J=7.6 \mathrm{~Hz}, 1$, bpy); ${ }^{13} \mathrm{C} \mathrm{NMR} \mathrm{(50} \mathrm{MHz,} \mathrm{CDCl}_{3}$, d) $38.88\left(\mathrm{COCH}_{3}\right), 122.11,123.05,126.09,126.66,139.39,149.74$, 150.41, 152.07, 154.39 (bpy), $231.38(\mathrm{CO})$; IR spectrum ( $\left.\mathrm{KBr}, \mathrm{cm}^{-1}\right)$ 1665 (CO). Anal. Calcd for $\mathrm{C}_{12} \mathrm{H}_{11} \mathrm{~N}_{2} \mathrm{BrOPd}$ : C, 37.38; $\mathrm{H}, 2.88 ; \mathrm{N}$, 7.27. Found: $36.51 ; \mathrm{H}, 2.70 ; \mathrm{N}, 7.40$.

PdI(COMe)(bpy) (4c): yield $85 \%$; mp $181{ }^{\circ} \mathrm{C} \mathrm{dec} ;{ }^{1} \mathrm{H}$ NMR (300 $\left.\mathrm{MHz} \mathrm{CDCl}_{3}, \delta\right) 2.71\left(\mathrm{~s}, 3, \mathrm{COCH}_{3}\right), 7.43$ (m, 1, bpy), 7.49 (m, 1, bpy), 7.98 (m, 1, bpy), 8.11 (m, 2, bpy), 8.25 (m, 2, bpy), 9.16 (d, $J=$ $4.7 \mathrm{~Hz}, 1$, bpy); ${ }^{13} \mathrm{C}$ NMR $\left(75 \mathrm{MHz}, \mathrm{CDCl}_{3}, \delta\right) 42.98\left(\mathrm{CH}_{3}\right), 121.84$, $122.69,126.28,126.63,138.96,139.18,150.13,151.72,152.27,154.47$ (bpy), $205.69(\mathrm{CO})$. IR spectrum $\left(\mathrm{KBr}, \mathrm{cm}^{-1}\right) 1678(\mathrm{CO})$. Anal. Calcd for $\mathrm{C}_{12} \mathrm{H}_{11} \mathrm{~N}_{2} \mathrm{IOPd}$ : C, 33.32; H, 2.57; N, 6.48. Found: C, 33.19; H, $2.56 ; \mathrm{N}, 6.35$.

(19) (a) Appleton, T. G.; Clark, H. C.; Manzer, L. E. Coord. Chem. Rev. 1973, 10, 335. (b) Appleton, T. G.; Bennett, M. A. Inorg. Chem. 1978, 17, 738. (c) Boere, R. T.; Willis, C. J. Inorg. Chem. 1985, 24, 1059.

(20) Ozawa, F.; Son, T.-i.; Osakada, K.; Yamamoto, A. J. Chem. Soc., Chem. Commun. 1989, 1067.

(21) de Graaf, W.; Boersma, J.; Smeets, W. J. J.; Spek, A. L.; van Koten, G. Organometallics 1989, 8, 2907.

(22) (a) Farmer, E. H.; Warren, F. L. J. Chem. Soc. 1929, 897. (b) Diels, O.: Alder, K. Chem. Ber. 1929, 62, 554.
Synthesis of $\mathrm{PdX}$ (COMe)(2,2'-bipyridyl) (4a-c) via CO Insertion. The following is a typical procedure: Through an ice-cooled solution of $1.13 \mathrm{~g}(2.8 \mathrm{mmol})$ of PdIMe(bpy) (3c) in $100 \mathrm{~mL}$ of methylene chloride, $\mathrm{CO}$ was bubbled for $1 \mathrm{~min}$ after which the vessel was closed. Stirring was continued for $2.5 \mathrm{~h}$ after which the resulting solution was filtered through filter aid, and the volatiles were evaporated in vacuo to give pure $4 \mathrm{c}$. Yield $1.17 \mathrm{~g}(97 \%)$. The complexes $4 \mathrm{a}, \mathrm{b}$ were obtained in similar yields.

NMR Studies of Alkene Insertions into Neutral Acetyl Complexes. A solution of $c a .30 \mathrm{mg}$ of the desired acetyl complex in 0.4 $\mathrm{mL}$ of $\mathrm{CDCl}_{3}$ or $\mathrm{CD}_{3} \mathrm{COCD}_{3}$ was prepared and filtered through cotton wool. Subsequently, 1.1 equiv of the appropriate alkene was added, and the reaction followed by ${ }^{1} \mathrm{H}$ NMR until the reaction was finished or resonances due to decomposition became visible.

General Procedure for the Insertion of Alkenes. The following is a typical procedure: To an ice-cooled solution of $0.20 \mathrm{~g}$ of PdI(COMe)(bpy) $(4 \mathrm{c})$ in $50 \mathrm{~mL}$ of methylene chloride were added 2.0 $\mathrm{mL}$ of acetonitrile, $56.4 \mathrm{mg}(0.60 \mathrm{mmol})$ of norbornene, and $0.16 \mathrm{~g}$ $(0.62 \mathrm{mmol})$ of silver trifluoromethanesulfonate upon which a white solid immediately precipitated. After stirring for $3 \mathrm{~h}$ at $0^{\circ} \mathrm{C}$ the solution was filtered through filter aid and the volatiles evaporated in vacuo. The resulting greenish-white product was washed once with $80 \mathrm{~mL}$ of diethyl ether and dried in vacuo: yield $0.23 \mathrm{~g}(91 \%)$. The products may be crystallized from acetone/pentane, methylene chloride/diethyl ether, or alcohols (methanol, ethanol).

[Pd(C $\left.\mathbf{C}_{7} \mathrm{H}_{10} \mathbf{C O M e}\right)\left(\right.$ tmeda)]OTf (7a): yield $93 \% ; \mathrm{mp} 89^{\circ} \mathrm{C} \mathrm{dec} ;{ }^{\prime} \mathrm{H}$ NMR $\left(300 \mathrm{MHz}, \mathrm{CDCl}_{3}, \delta\right) 1.30$ (m, 4, nbn), 1.61 (m, 2, nbn), 2.07 (m, 2, nbn), 2.27 (s, 3, COCH $\left.H_{3}\right), 2.41(\mathrm{~d}, J=3.9 \mathrm{~Hz}, 1, \mathrm{nbn}), 2.57$ (s, 3, $\mathrm{NMe}_{2}$ ), 2.62 (s, 3, $\mathrm{NMe}_{2}$ ), 2.65 (m, 4, nbn or tmeda), 2.66 (s, 3, $\left.\mathrm{NMe}_{2}\right), 2.71$ (s, 3, $\mathrm{NMe}_{2}$ ), 2.97 (m, 1, nbn or tmeda); ${ }^{13} \mathrm{C}$ NMR (75 $\left.\mathrm{MHz}, \mathrm{CDCl}_{3}, \delta\right) 27.16\left(\mathrm{COCH}_{3}\right), 29.36,29.57,36.64,41.62,42.98$, $47.71,48.08,48.56,50.58,52.68,56.72,64.04,71.01$ (alkyl, nbn + tmeda), $238.70\left(\mathrm{CO}^{23}\right)$; IR spectrum $\left(\mathrm{KBr}, \mathrm{cm}^{-1}\right) 1595$ (CO). Anal. Calcd for $\mathrm{C}_{16} \mathrm{H}_{29} \mathrm{~N}_{2} \mathrm{~F}_{3} \mathrm{O}_{4} \mathrm{PdS}$ : C, 37.76; $\mathrm{H}, 5.75 ; \mathrm{N}, 5.50$. Found: $\mathrm{C}$, 37.13; H, 5.21; N, 5.58 .

[Pd(C, $\left.\mathrm{H}_{8} \mathrm{COMe}\right)\left(\right.$ tmeda)]OTf (7b): yield $93 \% ; \mathrm{mp} 109^{\circ} \mathrm{C}$ dec; ${ }^{1} \mathrm{H}$ NMR $\left(300 \mathrm{MHz}, \mathrm{CD}_{3} \mathrm{COCD}_{3}, \delta\right) 1.38(\mathrm{~d}, J=9.2 \mathrm{~Hz}, 1, \mathrm{nbd}), 1.62$ (d, $J=9.5 \mathrm{~Hz}, 1, \mathrm{nbd}), 1.70$ (dd, $\mathrm{J}=6.2$ and $2.5 \mathrm{~Hz}, 1, \mathrm{nbd}), 2.56(\mathrm{~s}$, 3, $\mathrm{COCH}_{3}$ ), 2.6-3.2 (m, 18, tmeda + nbd), 3.38 (s, $1 \mathrm{nbd}$ ), 6.32 (m, 2, alkenyl, nbd); ${ }^{13} \mathrm{C}$ NMR $\left(75 \mathrm{MHz}, \mathrm{CD}_{3} \mathrm{COCD}_{3}, \delta\right) 27.45\left(\mathrm{COCH}_{3}\right)$, $39.59,45.31,47.49,47.97,48.33,49.40,51.25,52.61,57.40,63.67$, 64.80 (alkyl, nbd + tmeda), 129.59, 132.94 (alkenyl, nbd), $239.28(\mathrm{CO})$; IR spectrum $\left(\mathrm{KBr}, \mathrm{cm}^{-1}\right) 1607$ (CO).

[Pd( $\left.\mathrm{C}_{10} \mathrm{H}_{12} \mathrm{COMe}\right)($ tmeda) $] \mathbf{O T f}(\mathbf{7 c})$ : yield $91 \% ; \mathrm{mp} 117^{\circ} \mathrm{C} \mathrm{dec}$; ${ }^{1} \mathrm{H}$ NMR ( $\left.300 \mathrm{MHz}, \mathrm{CDCl}_{3}, \delta\right) 1.58(\mathrm{t}, J=10.0 \mathrm{~Hz}, 1$, diCp), $1.8-$ 3.3 (m, 28, tmeda + diCp), 5.4-5.8 (mmmm, 4, alkenyl, diCp, isomer ratio $1: 1.1) ;{ }^{13} \mathrm{C}$ NMR $\left(75 \mathrm{MHz}, \mathrm{CDCl}_{3}, \delta\right) 26.90,27.06\left(\mathrm{COCH}_{3}\right)$; $32.43,32.58,39.00,39.32,39.71,42.00,42.57,44.00,44.36,45.76$, $46.43,47.30,47.62,48.62,48.92,50.00,50.58,52.42,52.70,52.74$, $53.15,56.65,64.11,65.05,67.61$ (alkyl, tmeda + diCp), 130.71, 131.43, 131.74, 133.05 (alkenyl, diCp), 239.61, $240.77(\mathrm{CO})$; $\mathbb{R}$ spectrum $(\mathrm{KBr}$, $\mathrm{cm}^{-1}$ ) 1605 (CO). Anal. Calcd for $\mathrm{C}_{19} \mathrm{H}_{31} \mathrm{~N}_{2} \mathrm{~F}_{3} \mathrm{O}_{4} \mathrm{PdS}$ : C, 41.72; $\mathrm{H}$, $5.71 ; \mathrm{N}, 5.12$. Found: $\mathrm{C}, 41.66 ; \mathrm{H}, 5.64 ; \mathrm{N}, 5.18$.

[Pd( $\left.\mathbf{C}_{7} \mathrm{H}_{10} \mathbf{C O M e}\right)\left(\right.$ bpy)]OTf (8a): yield $91 \%$; mp $115^{\circ} \mathrm{C} \mathrm{dec;}{ }^{1} \mathrm{H}$ NMR ( $\left.300 \mathrm{MHz}, \mathrm{CDCl}_{3}, \delta\right) 1.36(\mathrm{~d}, J=10.2 \mathrm{~Hz}, 1, \mathrm{nbn}), 1.47$ (m, 2 , nbn), $1.74(\mathrm{~m}, 2, \mathrm{nbn}), 1.90(\mathrm{~d}, J=10.2 \mathrm{~Hz}, 1, \mathrm{nbn}), 2.26$ (s, br, 1 , nbn), $2.48\left(\mathrm{~s}, 3, \mathrm{COCH}_{3}\right), 2.57(\mathrm{~s}, \mathrm{br}, 1, \mathrm{nbn}), 2.69(\mathrm{~d}, J=4.5 \mathrm{~Hz}, 1$, nbn), 2.91 (d, $J=6.3 \mathrm{~Hz}, 1$, nbn), 7.64 (m, 2, bpy), 8.21 (m, 2, bpy), 8.34 (d, 1, bpy), 8.56 (m, 3, bpy); ${ }^{13} \mathrm{C}$ NMR (75 MHz, $\left.\mathrm{CDCl}_{3}, \delta\right) 27.44$ $\left(\mathrm{COCH}_{3}\right), 29.58,29.67,36.94,43.05,43.33,53.01,70.82$ (nbn), 123.34, $124.36,127.38,127.77,140.64,140.87,148.62,150.59,152.11,156.50$ (bpy), $240.83\left(\mathrm{CO}^{23}\right)$; IR spectrum $\left(\mathrm{KBr}, \mathrm{cm}^{-1}\right) 1598(\mathrm{CO})$. Anal. Calcd for $\mathrm{C}_{20} \mathrm{H}_{21} \mathrm{~N}_{2} \mathrm{~F}_{3} \mathrm{O}_{4} \mathrm{PdS}$ : C, $43.77 ; \mathrm{H}, 3.86 ; \mathrm{N}, 5.10$. Found: $\mathrm{C}, 43.49$; $\mathrm{H}, 3.97$; N, 5.19.

$\left[\mathbf{P d}\left(\mathrm{C}_{7} \mathrm{H}_{8} \mathrm{COMe}\right)(\mathrm{bpy})\right] \mathbf{O T f}(\mathbf{8 b}):$ yield $83 \% ; \mathrm{mp} 153{ }^{\circ} \mathrm{C} \mathrm{dec} ;{ }^{1} \mathrm{H}$ $\operatorname{NMR}\left(300 \mathrm{MHz}, \mathrm{CDCl}_{3}, \delta\right) 1.47(\mathrm{~d}, J=8.9 \mathrm{~Hz}, 1, \mathrm{nbd}), 1.79(\mathrm{~d}, J=$ $8.9 \mathrm{~Hz}, 1, \mathrm{nbd}$ ), 2.21 (dd, $J=6.0$ and $2.2 \mathrm{~Hz}, 1, \mathrm{nbd}$ ), 2.59 (s, 3, $\mathrm{COCH}_{3}$ ), 2.69 (d, $\left.J=5.9 \mathrm{~Hz}, 1, \mathrm{nbd}\right), 2.94$ (s, 1, nbd), 3.20 (s, 1, nbd), 6.24 (m, 2, alkenyl, nbd), 7.65 (m, 1, bpy), 7.72 (m, 1, bpy), 8.20 (m, 2, bpy), 8.43 (d, $J=5.4 \mathrm{~Hz}, 1$, bpy), 8.54 (m, 2, bpy), 8.60 $(\mathrm{d}, J=5.7 \mathrm{~Hz}, 1$, bpy $) ;{ }^{13} \mathrm{C} \mathrm{NMR}\left(75 \mathrm{MHz}, \mathrm{CDCl}_{3}, \delta\right) 27.58\left(\mathrm{COCH}_{3}\right)$, 45.81, 46.33, 47.71, 48.81, 63.48 (alkyl, nbd), 123.58, 124.65, 127.33 $127.83,133.47,136.30,140.75,140.99,148.35,150.34,152.26,156.58$ 
(bpy + alkenyl, nbd), 239.01 (CO); IR spectrum $\left(\mathrm{KBr}, \mathrm{cm}^{-1}\right) 1603$ (CO). Anal. Calcd for $\mathrm{C}_{20} \mathrm{H}_{19} \mathrm{~N}_{2} \mathrm{~F}_{3} \mathrm{O}_{4} \mathrm{PdS}$ : C, 43.93; H, 3.50; N, 5.12. Found: C, 43.76; H, 3.58; N, 5.15.

$\left[\mathbf{P d}\left(\mathrm{C}_{10} \mathrm{H}_{12} \mathrm{COMe}\right)(\mathrm{bpy})\right] \mathrm{OTf}(8 \mathrm{c})$ : yield $85 \% ; \mathrm{mp} 141^{\circ} \mathrm{C} \mathrm{dec} ;{ }^{1} \mathrm{H}$ NMR $\left(300 \mathrm{MHz}, \mathrm{CDCl}_{3}, \delta\right) 1.65\left(\mathrm{~m}, 6\right.$, alkyl and $\left.\mathrm{H}_{2} \mathrm{O}\right), 2.1-3.3(\mathrm{~m}$, 12, alkyl), 5.6-5.9 (mmm, 2, alkenyl, isomer ratio ca. 1:1.7), $7.64(\mathrm{~m}$, 2, bpy), 8.24 (m, 3, bpy), 8.62 (m, 3, bpy); ${ }^{13} \mathrm{C} \mathrm{NMR} \mathrm{(75} \mathrm{MHz,} \mathrm{CD}_{2^{-}}$ $\left.\mathrm{Cl}_{2}, \delta\right) 29.00,29.16\left(\mathrm{COCH}_{3}\right), 34.38,34.86,41.10,41.64,44.33,44.69$, $46.28,47.73,48.72,49.14,49.87,50.96,66.91,69.46$ (alkyl, diCp), $124.82,125.83,125.88,129.35,129.55,132.87,133.67,133.89,134.92$, $142.42,142.59,142.61,150.65,152.16,152.32,154.12,158.69,158.73$ (bpy + alkenyl, diCp), 243.45, $244.68\left(\mathrm{CO}^{23}\right)$; IR spectrum $\left(\mathrm{KBr}, \mathrm{cm}^{-1}\right)$ 1601 (CO). Anal. Calcd for $\mathrm{C}_{23} \mathrm{H}_{23} \mathrm{~N}_{2} \mathrm{~F}_{3} \mathrm{O}_{4} \mathrm{PdS}$ : C, 47.07; H, 3.95; $\mathrm{N}, 4.77$. Found: $\mathrm{C}, 46.31 ; \mathrm{H}, 3.89 ; \mathrm{N}, 4.67$.

[Pd( $\left.\left.\mathrm{C}_{9} \mathrm{H}_{8} \mathrm{O}_{3} \mathrm{COMe}\right)(\mathrm{bpy})\right]$ OTf (8d): yield $93 \% ; \mathrm{mp} 167^{\circ} \mathrm{C} \mathrm{dec}$ ${ }^{1} \mathrm{H}$ NMR $\left(300 \mathrm{MHz}, \mathrm{CD}_{3} \mathrm{COCD}_{3}, \delta\right) 1.98\left(\mathrm{~d}, J=10.9 \mathrm{~Hz}, 1 \mathrm{C}_{9} \mathrm{H}_{8} \mathrm{O}_{3}\right)$, 2.39 (d, $\left.J=10.9 \mathrm{~Hz}, 1, \mathrm{C}_{9} \mathrm{H}_{8} \mathrm{O}_{3}\right), 2.66\left(\mathrm{~s}, 3, \mathrm{COCH}_{3}\right), 2.85(\mathrm{~m}, 2$, $\left.\mathrm{C}_{9} \mathrm{H}_{8} \mathrm{O}_{3}\right), 3.23$ (d, $\left.J=6.7 \mathrm{~Hz}, 1, \mathrm{C}_{9} \mathrm{H}_{8} \mathrm{O}_{3}\right), 3.33(\mathrm{~d}, J=5.4 \mathrm{~Hz}, 1$, $\left.\mathrm{C}_{9} \mathrm{H}_{8} \mathrm{O}_{3}\right), 3.71\left(\mathrm{~m}, 1, \mathrm{C}_{9} \mathrm{H}_{8} \mathrm{O}_{3}\right), 3.94\left(\mathrm{~m}, 1, \mathrm{C}_{9} \mathrm{H}_{8} \mathrm{O}_{3}\right), 7.90$ (m, 2, bpy), 8.39 (m, 3, bpy), $8.66(\mathrm{~m}, 2, \mathrm{bpy}), 8.79\left(\mathrm{~d}, J=5.2 \mathrm{~Hz}, \mathrm{l}\right.$, bpy); ${ }^{13} \mathrm{C}$ NMR (50 MHz, CD $\left.{ }_{3} \mathrm{CN}, \delta\right) 28.29\left(\mathrm{COCH}_{3}\right), 41.11,43.90,45.83,45.93$, 50.42, 51.30, 66.68 (alkyl, $\mathrm{C}_{9} \mathrm{H}_{8} \mathrm{O}_{3}$ ), 124.11, 125.08, 128.87, 128.99, $141.93,142.02,149.75,151.34,153.31,157.81$ (bpy), 173.01, 174.14 $\left(\mathrm{CO}, \mathrm{C}_{9} \mathrm{H}_{8} \mathrm{O}_{3}\right), 242.52\left(\mathrm{COCH}_{3}\right)$; IR spectrum $\left(\mathrm{KBr}, \mathrm{cm}^{-1}\right) 1604(\mathrm{CO})$. Anal. Calcd for $\mathrm{C}_{22} \mathrm{H}_{19} \mathrm{~N}_{2} \mathrm{~F}_{3} \mathrm{O}_{7} \mathrm{PdS}$ : C, 42.70; H, 3.09; N, 4.53. Found: $\mathrm{C}, 42.61 ; \mathrm{H}, 3.15 ; \mathrm{N}, 4.46$.

$\left[\mathrm{Pd}\left(\mathrm{C}_{8} \mathrm{H}_{6} \mathrm{O}_{4} \mathrm{COMe}\right)(\mathrm{bpy})\right] \mathrm{OTf}(8 \mathrm{e})$ : yield $96 \% ; \mathrm{mp} 165^{\circ} \mathrm{C} \mathrm{dec}$; ${ }^{1} \mathrm{H}$ NMR $\left(300 \mathrm{MHz}, \mathrm{CD}_{3} \mathrm{CN}, \delta\right) 2.57\left(3, \mathrm{~s}, \mathrm{COCH}_{3}\right), 2.89(\mathrm{~d}, J=7.0$ $\left.\mathrm{Hz}, 1, \mathrm{C}_{8} \mathrm{H}_{6} \mathrm{O}_{4}\right), 3.47\left(\mathrm{~d}, J=7.0 \mathrm{~Hz}, 1, \mathrm{C}_{8} \mathrm{H}_{6} \mathrm{O}_{4}\right), 3.64\left(\mathrm{AB}, 2, \mathrm{C}_{8} \mathrm{H}_{6} \mathrm{O}_{4}\right)$, $4.87\left(\mathrm{~s}, 1, \mathrm{C}_{8} \mathrm{H}_{6} \mathrm{O}_{4}\right), 5.24\left(\mathrm{~s}, 1, \mathrm{C}_{8} \mathrm{H}_{6} \mathrm{O}_{4}\right), 7.72(\mathrm{~m}, 2, \mathrm{bpy}), 8.26(\mathrm{~m}, 4$, bpy), 8.43 (d, $J=5.3 \mathrm{~Hz}, 1$, bpy), 8.55 (d, $J=5.3 \mathrm{~Hz}, 1$, bpy); ${ }^{13} \mathrm{C}$ NMR $\left(50 \mathrm{MHz}, \mathrm{CD}_{3} \mathrm{CN}, \delta\right) 28.54\left(\mathrm{COCH}_{3}\right), 43.97,51.25,51.54,68.46$, $83.94,87.26$ (alkyl, $\mathrm{C}_{8} \mathrm{H}_{6} \mathrm{O}_{4}$ ) $, 124.08,125.01,128.82,129.05,141.95$, $142.10,149.77,152.62,153.57,157.77$ (bpy), 171.57, 172.71 (CO, $\left.\mathrm{C}_{8} \mathrm{H}_{6} \mathrm{O}_{4}\right), 239.54\left(\mathrm{COCH}_{3}\right)$; IR spectrum $\left(\mathrm{KBr}, \mathrm{cm}^{-1}\right) 1604(\mathrm{CO})$. Anal. Calcd for $\mathrm{C}_{21} \mathrm{H}_{17} \mathrm{~N}_{2} \mathrm{~F}_{3} \mathrm{O}_{8} \mathrm{PdS}$ : C, $40.63 ; \mathrm{H}, 2.76 ; \mathrm{N}, 4.51$. Found: C, $40.51 ; \mathrm{H}, 2.87 ; \mathrm{N}, 4.58$.

Synthesis of [(tmeda)Pd $\left\{\mathrm{C}_{7} \mathrm{H}_{3}(\mathrm{COMe})_{2}-2,5\right\} \mathrm{Pd}($ tmeda $\left.)\right](\mathrm{OTf})_{2}$ (9). To an ice-cooled solution of $0.57 \mathrm{~g}(1.5 \mathrm{mmol})$ of PdI(COMe)(tmeda) (2c) in $25 \mathrm{~mL}$ of methylene chloride was added $1 \mathrm{~mL}$ of acetonitrile and $0.38 \mathrm{~g}(1.5 \mathrm{mmol})$ of silver trifluoromethanesulfonate. To the resulting white suspension, a solution of $0.07 \mathrm{~g}(0.76 \mathrm{mmol})$ of norbornadiene in $20 \mathrm{~mL}$ of methylene chloride was added dropwise over ca. $15 \mathrm{~min}$. After stirring the solution for $3 \mathrm{~h}$ at $0{ }^{\circ} \mathrm{C}$ and overnight at ambient temperature, the greyish suspension was filtered through filter-aid. The volatiles were then removed in vacuo to yield $0.72 \mathrm{~g}$ $(107 \%)$ of a yellow oil. Solid 9 was obtained from methanol/diethyl ether: yield $0.33 \mathrm{~g} \mathrm{(49 \% )}$ of light-yellow needles; mp $134{ }^{\circ} \mathrm{C} \mathrm{dec} ;{ }^{\prime} \mathrm{H}$ NMR (300 MHz, $\left.\mathrm{CD}_{3} \mathrm{COCD}_{3}, \delta\right) 1.83$ (s, 2, nbd), 2.39 (d, $J=6.6 \mathrm{~Hz}$, 2, nbd), 2.46 (s, 6, $\left.\mathrm{COCH}_{3}\right), 2.65(\mathrm{~d}, J=4.6 \mathrm{~Hz}, 2$, nbd), 2.68 (s, 6 , $\mathrm{NMe}_{2}$ ), 2.75 (s, 6, $\mathrm{NMe}_{2}$ ), 2.80 (m, 4, $-\mathrm{CH}_{2}-$, tmeda); 2.88 (m, 8, tmeda); 2.94 (s, $6 \mathrm{NMe}_{2}$ ), 3.02 (t, $J=5.5 \mathrm{~Hz}, 2,-\mathrm{CH}_{2}-$, tmeda), $3.11\left(\mathrm{~d}, J=6.5 \mathrm{~Hz}, 2\right.$, nbd); ${ }^{13} \mathrm{C} \mathrm{NMR}\left(50 \mathrm{MHz}, \mathrm{CD}_{3} \mathrm{COCD}_{3}, \delta\right) 27.59$ $\left(\mathrm{COCH}_{3}\right) ; 35.41,45.91,48.10,48.34,48.73,51.73,52.61,57.38,64.69$. 71.03 (nbd + tmeda), $238.62(\mathrm{CO})$; IR $\left(\mathrm{KBr}, \mathrm{cm}^{-1}\right) 1606(\mathrm{CO})$. Anal. Calcd. for $\mathrm{C}_{25} \mathrm{H}_{46} \mathrm{~N}_{4} \mathrm{~F}_{6} \mathrm{O}_{8} \mathrm{Pd}_{2} \mathrm{~S}_{2}:$ C, 32.58; H, 5.03; N, 6.08. Found: C, 32.54; H, 4.92; N, 6.25.

Synthesis of [(bpy)Pd $\left.\left\{\mathrm{C}_{7} \mathrm{H}_{8}(\mathrm{COMe})_{2}-2,5\right\} \mathrm{Pd}(\mathrm{bpy})\right](\mathrm{OTf})_{2}$ (10). To an ice-cooled solution of $0.55 \mathrm{~g}(1.3 \mathrm{mmol})$ of PdI(COMe)(bpy) $(\mathbf{4 c})$ in $50 \mathrm{~mL}$ of methylene chloride was added $1 \mathrm{~mL}$ of acetonitrile and $0.34 \mathrm{~g}(1.3 \mathrm{mmol})$ of silver trifluoromethanesulfonate. To the resulting white suspension, a solution of $0.06 \mathrm{~g}(0.65 \mathrm{mmol})$ of norbornadiene in $20 \mathrm{~mL}$ of methylene chloride was added dropwise over ca. $15 \mathrm{~min}$. After stirring the solution for $3 \mathrm{~h}$ at $0^{\circ} \mathrm{C}$ and overnight at ambient temperature, the greyish suspension was filtered through filter-aid, and the residue washed with $2 \times 100 \mathrm{~mL}$ of acetonitrile. The volatiles were then removed in vacuo to give a light yellow solid. The product was washed with $3 \times 30 \mathrm{~mL}$ of diethyl ether and $3 \times 30$ $\mathrm{mL}$ of methylene chloride and subsequently dried in vacuo: yield 0.30 $\mathrm{g}(47 \%)$. The product is only slightly soluble in acetonitrile, while it is insoluble in methylene chloride, alcohols, and acetone: $\mathrm{mp} 154^{\circ} \mathrm{C}$ dec; IR (KBr, cm $\left.{ }^{-1}\right) 1601$ (CO). Anal. Calcd for $\mathrm{C}_{33} \mathrm{H}_{30} \mathrm{~N}_{4} \mathrm{~F}_{6} \mathrm{O}_{8}$ $\mathrm{Pd}_{2} \mathrm{~S}_{2}$ : C, $39.57 ; \mathrm{H}, 3.02 ; \mathrm{N}, 5.59$. Found: C, 39.36; H, 3.10; N, 5.68.
Synthesis of $\mathrm{PdCl}\left(\mathrm{COC}_{7} \mathrm{H}_{10} \mathrm{COMe}\right)(\mathrm{bpy})$ (12a). To a cold ( -30 $\left.{ }^{\circ} \mathrm{C}\right)$ solution of $2.59 \mathrm{~g}(4.7 \mathrm{mmol})\left[\mathrm{Pd}\left(\mathrm{C}_{7} \mathrm{H}_{10} \mathrm{COMe}\right)(\mathrm{bpy})\right] \mathrm{OTf}(8 \mathrm{c})$ in $150 \mathrm{~mL}$ of acetone was added $6.34 \mathrm{~g}(108.5 \mathrm{mmol})$ of sodium chloride. Carbon monoxide ( $1 \mathrm{~atm})$ was bubbled through the suspension for 2 min after which the reaction mixture was stirred at $-30^{\circ} \mathrm{C}$ for $1 \mathrm{~h}$. This procedure was repeated seven times. The mixture was diluted with $50 \mathrm{~mL}$ of methylene chloride and subsequently filtered through filter aid. After concentrating the filtrate to a few milliliters, $80 \mathrm{~mL}$ of pentane were added, and the bright yellow precipitate was collected. Recrystallization was done from methylene chloride/pentane: yield 83\%; mp $122{ }^{\circ} \mathrm{C} \mathrm{dec} ;{ }^{1} \mathrm{H}$ NMR (300 MHz, $\left.\mathrm{CDCl}_{3}, \delta\right) 1.0-1.7$ (m, 6, nbn), 2.22 (s, 3, $\mathrm{COCH}_{3}$ ), 2.47 (s, 1, nbn), 2.60 (d, $J=9.2 \mathrm{~Hz}, 1$, nbn), 3.18 (s, 1, nbn), 4.02 (d, $J=9.2 \mathrm{~Hz}, 1, \mathrm{nbn}), 7.43$ (m, 2, bpy), 8.07 (m, 4, bpy), 8.31 (d, $J=4.6 \mathrm{~Hz}, 1$, bpy), 8.87 (d, $J=4.7 \mathrm{~Hz}, 1$, bpy); ${ }^{13} \mathrm{C}$ NMR (75 MHz, $\mathrm{CDCl}_{3}, \delta$ ) $29.00,29.12$ (nbn), 31.46 $\left(\mathrm{COCH}_{3}\right), 34.98,38.81,39.16,58.64,67.62$ (nbn), 121.69, 122.46, $125.93,126.60,139.08,139.36,149.20,151.34,152.33,154.50$ (bpy); 210.92, $230.63(\mathrm{CO})$; IR spectrum $\left(\mathrm{KBr}, \mathrm{cm}^{-1}\right)$ 1672, $1710(\mathrm{CO})$. Anal. Calcd for $\mathrm{C}_{20} \mathrm{H}_{21} \mathrm{~N}_{2} \mathrm{ClO}_{2} \mathrm{Pd}: \mathrm{C}, 51.85 ; \mathrm{H}, 4.57 ; \mathrm{N}, 6.05$. Found: $\mathrm{C}$, 51.36; H, 4.50; N, 5.84.

Synthesis of $\mathrm{PdI}\left(\mathrm{COC}_{7} \mathrm{H}_{10} \mathrm{COMe}\right)(\mathrm{bpy})$ (12b). This complex was prepared similarly to 12a using 20 equiv of sodium iodide, although the insertion procedure was repeated only 4 times: yield $93 \%$; mp 144 ${ }^{\circ} \mathrm{C} \mathrm{dec}$; ${ }^{1} \mathrm{H}$ NMR $\left(300 \mathrm{MHz}, \mathrm{CDCl}_{3}, \delta\right) 1.12$ (m, 2, nbn), 1.49 (m, 4, nbn), 2.30 (s, 3, $\left.\mathrm{COCH}_{3}\right), 2.51$ (m, 2, nbn), 3.45 (s, br, 1, nbn), 3.96 (d, $J=9.3 \mathrm{~Hz}, 1, \mathrm{nbn}), 7.44$ (m, 1, bpy), 7.51 (m, 1, bpy), 7.99 (m, 1, bpy), 8.10 (m, 3, bpy), 8.33 (d, $J=4.6 \mathrm{~Hz}, 1$, bpy), 9.25 (d, $J=5.2$ $\mathrm{Hz}, 1$, bpy); ${ }^{33} \mathrm{C} \mathrm{NMR}\left(50 \mathrm{MHz}, \mathrm{CD}_{2} \mathrm{Cl}_{2}, \delta\right) 28.89,29.24$ (nbn), 32.29 $\left(\mathrm{COCH}_{3}\right), 35.38,38.54,39.37,58.34,75.05$ (nbn), 122.21, 122.87, $126.12,126.51,139.19,139.28,150.76,151.54,152.34,154.33$ (bpy), 211.37, 299.73 (CO); IR spectrum $\left(\mathrm{KBr}, \mathrm{cm}^{-1}\right)$ 1663, 1706 (CO). Anal. Calcd for $\mathrm{C}_{20} \mathrm{H}_{21} \mathrm{~N}_{2} \mathrm{IO}_{2} \mathrm{Pd}$ : C, 43.30; $\mathrm{H}, 3.82 ; \mathrm{N}, 5.05$. Found: $\mathrm{C}, 42.75$; $\mathrm{H}, 3.84 ; \mathrm{N}, 4.81$.

Alternative Synthesis of $12 \mathrm{~b}$. To an ice-cold solution of $0.05 \mathrm{~g}$ $(0.11 \mathrm{mmol})$ of 12a in $25 \mathrm{~mL}$ of acetone was added $0.07 \mathrm{~g}(0.47 \mathrm{mmol})$ of sodium iodide. The mixture was stirred at $0^{\circ} \mathrm{C}$ for $3 \mathrm{~h}$ after which the white precipitate was filtered off, and the filtrate was concentrated to a few milliliter. Addition of $50 \mathrm{~mL}$ of pentane gave pure orangecolored $\mathbf{1 2 b}$, which was dried in vacuo: yield $83 \%$.

Synthesis of $\left[\mathrm{Pd}\left(\mathrm{C}_{7} \mathrm{H}_{10} \mathrm{COC}_{7} \mathrm{H}_{10} \mathrm{COMe}\right)(\mathrm{bpy})\right] \mathrm{OTf}(13 \mathrm{a})$. This complex was obtained via the general alkene insertion procedure: yield $86 \%$; mp $121^{\circ} \mathrm{C} \mathrm{dec} ;{ }^{1} \mathrm{H}$ NMR $\left(300 \mathrm{MHz}, \mathrm{CDCl}_{3}, \delta\right) 1.2-1.9(\mathrm{~m}, 10$, nbn), 2.00 (s, br, 1, nbn), 2.09 (m, 1, nbn), 2.26 (s, 4, nbn + $\mathrm{COCH}_{3}$ ), 2.48 (s, br, $1, \mathrm{nbn}), 2.53$ (d, $J=6.0 \mathrm{~Hz}, 1, \mathrm{nbn}), 2.62(\mathrm{~d}, J=2.6 \mathrm{~Hz}$, $1, \mathrm{nbn}), 2.67$ (d, $J=3.5 \mathrm{~Hz}, 1, \mathrm{nbn}), 2.74(\mathrm{~d}, J=5.2 \mathrm{~Hz}, 1, \mathrm{nbn}), 3.02$ (d, $J=9.1 \mathrm{~Hz}, 1, \mathrm{nbn}$ ), 3.42 (d, $J=9.1 \mathrm{~Hz}, 1, \mathrm{nbn}), 7.65$ (m, 2, bpy), 8.20 (m, 2, bpy), 8.38 (d, $J=5.2 \mathrm{~Hz}, 1$, bpy), 8.50 (m, 3, bpy); ${ }^{13} \mathrm{C}$ NMR (75 MHz, $\mathrm{CDCl}_{3}, \delta$ ) 28.59, 28.75, 29.09, 29.22, 30.45, 35.56, $37.48,39.39,40.66,43.33,44.25,52.33,52.95,65.32,70.49$ (nbn + $\left.\mathrm{COCH}_{3}\right), 123.34,124.28,127.47,127.57,140.62,140.72,148.45$, 150.35, 152.10, 156.48 (bpy), 208.00, 243.39 (CO); IR spectrum ( $\mathrm{KBr}$, $\mathrm{cm}^{-1}$ ) 1582, 1708 (CO). Anal. Calcd for $\mathrm{C}_{28} \mathrm{H}_{31} \mathrm{~N}_{2} \mathrm{~F}_{3} \mathrm{O}_{5} \mathrm{PdS}$ : C, 50.12; $\mathrm{H}, 4.66 ; \mathrm{N}, 4.17$. Found: C, 49.96; H, 4.78; N, 4.13.

Synthesis of $\left[\mathrm{Pd}\left(\mathrm{C}_{7} \mathrm{H}_{8} \mathrm{COC}_{7} \mathrm{H}_{10} \mathrm{COMe}\right)(\mathrm{bpy})\right]$ OTf (13b). This complex was obtained via the general alkene insertion procedure: yield $89 \%$; mp $147^{\circ} \mathrm{C} \mathrm{dec} ;{ }^{1} \mathrm{H}$ NMR $\left(200 \mathrm{MHz}, \mathrm{CD}_{3} \mathrm{COCD}_{3}, \delta\right) 1.3-1.8$ (m, 8H, nbn), 2.02 (m, 1, nbn), 2.28 (s, 3, COCH $\mathrm{COC}_{3}, 2.32$ (m, 2, nbn), $2.55(\mathrm{~m}, 1, \mathrm{nbn}), 2.75(\mathrm{~m}, 2, \mathrm{nbn}), 3.13(\mathrm{~m}, 1 \mathrm{nbn}), 3.40(\mathrm{~m}, 2, \mathrm{nbn})$, 3.75 (m, 1, nbn), 6.33 (m, 2, nbd), 7.88 (m, 2, bpy), 8.35 (m, 2, bpy), 8.65 (m, 2, bpy), $8.78\left(\mathrm{~m}, 2\right.$, bpy); ${ }^{13} \mathrm{C}$ NMR $\left(75 \mathrm{MHz}, \mathrm{CD}_{3} \mathrm{COCD}_{3}\right.$, d) $28.59\left(\mathrm{COCH}_{3}\right), 35.98,40.12,41.65,45.75,46.29,49.10,50.51$, $53.46,63.67,65.92$, (alkyl), 124.01, 124.89, 128.66, 128.94, 133.53, $135.09,141.61,149.55,152.21,153.53,157.58$ (alkenyl + pyridyl), 208.17, 243.53 (CO); IR spectrum ( $\left.\mathrm{KBr}, \mathrm{cm}^{-1}\right) 1587,1698$ (CO). Anal. Calcd for $\mathrm{C}_{56} \mathrm{H}_{58} \mathrm{~N}_{4} \mathrm{AgF}_{6} \mathrm{IO}_{10} \mathrm{Pd}_{2} \mathrm{~S}_{2}: \mathrm{C}, 42.76 ; \mathrm{H}, 3.72 ; \mathrm{N}, 3.56$. Found: $\mathrm{C}, 41.95 ; \mathrm{H}, 3.62 ; \mathrm{N}, 3.48$.

Synthesis of $\left[\mathrm{Pd}\left(\mathrm{C}_{9} \mathrm{H}_{8} \mathrm{O}_{3} \mathrm{COC}_{7} \mathrm{H}_{10} \mathrm{COMe}\right)(\right.$ bpy)]OTf (13c). This complex was prepared via the general alkene insertion procedure but could not be purified: yield $72 \%$; IR spectrum $\left(\mathrm{KBr}, \mathrm{cm}^{-1}\right) 1601,1698$, 1778 (CO).

Synthesis of $\mathrm{PdI}\left(\mathrm{COC}_{7} \mathrm{H}_{10} \mathrm{COC}_{7} \mathrm{H}_{10} \mathrm{COMe}\right)(\mathrm{bpy})$ (14). This complex was prepared similarly to $12 \mathrm{~b}$ : yield $93 \%$; mp $118^{\circ} \mathrm{C} \mathrm{dec} ;{ }^{1} \mathrm{H}$ NMR $\left(300 \mathrm{MHz}, \mathrm{CDCl}_{3}, \delta\right) 1.07$ (d, $\left.J=9.9 \mathrm{~Hz}, 1, \mathrm{nbn}\right), 1.19$ (m, 3, 
nbn), 1.57 (m, 8, nbn), $2.27\left(\mathrm{~m}, 4, \mathrm{nbn}+\mathrm{COCH}_{3}\right), 2.54(\mathrm{~m}, 3, \mathrm{nbn})$, 2.78 (d, $J=9.3 \mathrm{~Hz}, 1, \mathrm{nbn}$ ), 3.48 (d, $J=9.1 \mathrm{~Hz}, 2, \mathrm{nbn}), 3.99$ (s, br, 1, nbn), 7.42 (m, 1, bpy), 7.61 (m, 1, bpy), 8.10 (m, 4, bpy), 8.26 (d, $J=5.0 \mathrm{~Hz}, 1$, bpy), $9.21(\mathrm{~d}, J=4.6 \mathrm{~Hz}, 1$, bpy $) ;{ }^{13} \mathrm{C} \mathrm{NMR}(75 \mathrm{MHz}$, $\left.\mathrm{CDCl}_{3}, \delta\right) 28.51,29.02,29.51,30.02,31.23,35.29,36.21,38.43,39.28$, $41.06,41.30,53.62,55.04,57.40,63.08,76.33\left(\mathrm{nbn}+\mathrm{COCH}_{3}\right), 121.79$, $122.43,126.39,126.96,139.12,139.20,151.40,151.80,152.41,154.55$ (bpy), 210.79, 213.34, $232.73(\mathrm{CO})$; IR spectrum $\left(\mathrm{KBr}, \mathrm{cm}^{-1}\right) 1669$, 1715 (CO). Anal. Calcd for $\mathrm{C}_{28} \mathrm{H}_{31} \mathrm{~N}_{2} \mathrm{IO}_{3} \mathrm{Pd}: \mathrm{C}, 49.68 ; \mathrm{H}, 4.62 ; \mathrm{N}$, 4.14. Found: $\mathrm{C}, 47.86 ; \mathrm{H}, 4.67 ; \mathrm{N}, 3.91$.

Spin-Saturation Transfer Measurements. Lattice relaxation times were obtained using standard Inversion Recovery methods (11 data points, $90^{\circ}\left(180^{\circ}\right)$ pulse width: $8(16) \mu$ s, relaxation delay: $25 \mathrm{~s}, 8$ scans per data point) at sample concentrations of $c a .50 \mathrm{mg} \mathrm{mL}^{-1}$. The temperature $\left( \pm 1^{\circ} \mathrm{C}\right)$ was checked externally against $\mathrm{CD}_{3} \mathrm{OD}$. The spectra for the Forsén-Hoffman experiments ${ }^{14}$ were measured using the $\left(T_{\mathrm{d}}-\pi / 2\right)_{\mathrm{n}}$ pulse sequence with a presaturation time $\left(T_{\mathrm{d}}\right)$ of $25 \mathrm{~s}$, relaxation delay $=25 \mathrm{~s}$, pulse width $4 \mu \mathrm{s}$.

$X$-ray Structure Determination of 8c, 9, and 14. Crystals of 8c, 9. and 14, suitable for X-ray diffraction, were glued to the tip of a glass fiber or sealed in a Lindemann glass capillary $(\mathbf{8 c})$ and transferred to an Enraf-Nonius CAD4-Turbo diffractometer with rotating anode (Mo K $\alpha$ radiation, graphite monochromator, $\lambda=0.71073 \AA$ ). Accurate unit-cell parameters and an orientation matrix were determined by leastsquares refinement of 25 well-centered reflections (SET4) in the range $14.2^{\circ}<\theta<17.8^{\circ}, 11.4<\theta<12.9^{\circ}$, and $9.9^{\circ}<\theta<13.9^{\circ}$ for $8 \mathbf{c}$, 9, and 14, respectively. Reduced-cell calculations did not indicate higher lattice symmetry. ${ }^{24}$ Crystal data and details on data collection and refinement are collected in Table 6. Data were corrected for $L p$ effects and for the observed linear decay of the reference reflections. For complexes $8 \mathrm{c}$ and $\mathbf{1 4}$ the standard deviations of the intensities, as obtained by counting statistics, were increased according to an analysis of the excess variance of the reference reflections: $\sigma^{2}(I)=\sigma_{c s}^{2}(I)+$ $(p I)^{2}$ with $p=0.04$ and 0.03 for $8 \mathrm{c}$ and 14, respectively. ${ }^{25}$ An empirical absorption/extinction correction was applied for all complexes (DIFABS $^{26}$ ). The structures were solved by automated Patterson methods and subsequent difference Fourier techniques (SHELXS86 ${ }^{27}$ for $8 \mathrm{c}$ and DIRDIF-92 ${ }^{28}$ for 9 and 14). Complexes $8 \mathrm{c}$ and 14 were refined on $F$ by full-matrix least-squares techniques (SHELX76 $6^{29}$ ). Complex 9 was refined on $F^{2}$ (SHELXL93 ${ }^{30}$ ); no observance criterium was applied during refinement. Hydrogen atoms were included in the refinement on calculated positions, riding on their carrier atoms. After anisotropic refinement of the non-hydrogen atoms of 9 and introduction of the hydrogen atoms at expected positions, an $R$-value of 0.093 was obtained. A difference Fourier revealed a large number of residual density peaks

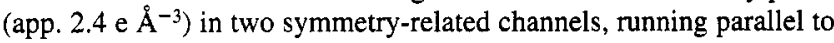

(23) Incorrectly reported in an earlier communication (ref. $8 \mathrm{~h}$ ).

(24) Spek, A. L. J. Appl. Crystallogr. 1988, 21, 578.

(25) McCandlish, L. E.; Stout, G. H.; Andrews, L. C. Acta Crystallogr. 1975, $A 31,245$.

(26) Walker, N.; Stuart, D. Acta Crystallogr. 1983, A39, 158.

(27) Sheldrick, G. M. SHELXS86 Program for Crystal Structure Determination; University of Göttingen, Germany, 1986.

(28) Beurskens, P. T.; Admiraal, G.; Beurskens, G.; Bosman, W. P. García-Granda, S.; Gould, R. O.; Smits, J. M. M.; Smykalla, C. The DIRDIF Program System; Technical report of the Crystallography Laboratory, University of Nijmegen, The Netherlands, 1992.

(29) Sheldrick, G. M. SHELX76 Program for Crystal Structure Determination; University of Cambridge, UK, 1976.

(30) Sheldrick, G. M. SHELXL93 Program for Crystal Structure Refinement; University of Göttingen, Germany, 1993. the $b$-axis and located at $x=0, z=3 / 4$ and at $x=1 / 2, z=1 / 4$. No discrete solvent model could be refined. The BYPASS procedure, ${ }^{31}$ as implemented in the program PLATON, ${ }^{32}$ was used to take this electron density into account. A total number of 93.5 electrons were found in the two channels, which had a volume of $205.7 \AA^{3}$ each. The channels are probably filled with diethyl ether, which was used in crystallization. The non-hydrogen atoms of all three structures were refined with anisotropic thermal parameters. The hydrogen atoms of $8 c$ were refined with two overall isotropic thermal parameters with values of $0.111(12)$ and $0.072(4) \AA^{2}$ for the hydrogen atoms of the methyl group and the other hydrogen atoms, respectively. The hydrogen atoms of 9 were refined with a fixed isotropic thermal parameter amounting to 1.5 or 1.2 times the value of the equivalent isotropic thermal parameter of their carrier atoms, for the methyl hydrogen atoms and the other hydrogen atoms, respectively. The hydrogen atoms of 14 were refined with two overall isotropic thermal parameters with values of $0.18(3)$ and $0.041(3) \AA^{2}$ for the hydrogen atoms located in the acetone solvent molecule and the hydrogen atoms in the palladium complex, respectively. The Flack $x$ parameter, ${ }^{33}$ derived during the structure-factor calculation of 9, amounted to 0.50 (5), indicating a possible racemic twin. Refinement of a twin model resulted in better $w R 2$ values and a component ratio of $0.49(4): 0.51$. Positional parameters are listed in Tables 7-9 for 8c, 9, and 14, respectively. Neutral atom scattering factors and anomalous dispersion corrections were taken from the International Tables for Crystallography ${ }^{34}$ for 9 . Complexes $8 \mathrm{c}$ and 14 were refined using neutral atom scattering factors taken from Cromer and $\mathrm{Mann}^{35}$ amplified with anomalous dispersion corrections from Cromer and Liberman. ${ }^{36} \mathrm{Geo}$ metrical calculations and illustrations were performed with PLATON; $;^{32}$ all calculations were performed on a DECstation 5000 cluster.

Acknowledgment. This work was supported in part (A.L.S.) by the Netherlands Foundation for Chemical Research (SON) with financial aid from the Netherlands Organization for Scientific Research (NWO).

Supplementary Material Available: Further details of the structure determinations, including atomic coordinates, bond lengths and angles, and thermal parameters for $8 \mathrm{c}, 9$, and 14 (14 pages). [Further details for the structure determinations of $8 c$ and 14 are available as supplementary material to the preliminary reports (refs $8 \mathrm{~h}$ and 81 , respectively).]; tables of observed and calculated structure factors (60 pages). This material is contained in many libraries on microfiche, immediately follows this article in the microfilm version of the journal, can be ordered from the ACS, and can be downloaded from the Internet; see any current masthead page for ordering information and Internet access instructions.

\section{JA942258T}

(31) van der Sluis, P.; Spek, A. L. Acta Crystallogr. 1990, A46, 194.

(32) Spek, A. L. Acta Crystallogr. 1990, A46, C34.

(33) Flack, H. D. Acta Crystallogr. 1983, A39, 876

(34) International Tables for Crystallography; Wilson, A. J. C. Ed; Kluwer Academic Publishers; Dordrecht, The Netherlands, 1992; Vol. C (35) Cromer, D. T.; Mann, J. B. Acta Crystallogr. 1968, A24, 321

(36) Cromer, D. T.; Liberman, D. J. Chem. Phys. 1970, 53, 1891. 